\title{
Review \\ The Complex Interplay between Endocannabinoid System and the Estrogen System in Central Nervous System and Periphery
}

\author{
Antonietta Santoro ${ }^{1, *}\left(\mathbb{D}\right.$, Elena Mele ${ }^{2}$, Marianna Marino ${ }^{1} \oplus$, Andrea Viggiano ${ }^{1}$, Stefania Lucia Nori ${ }^{3}$ \\ and Rosaria Meccariello $2, *$ (D) \\ 1 Department of Medicine, Surgery and Dentistry "Scuola Medica Salernitana", University of Salerno, \\ 84081 Baronissi, Italy; mamarino@unisa.it (M.M.); aviggiano@unisa.it (A.V.) \\ 2 Department of Movement Sciences and Wellbeing, Parthenope University of Naples, 80133 Naples, Italy; \\ elena.mele@collaboratore.uniparthenope.it \\ 3 Department of Pharmacy, University of Salerno, 84084 Fisciano, Italy; snori@unisa.it \\ * Correspondence: ansantoro@unisa.it (A.S.); meccariello@uniparthenope.it (R.M.); Tel.: +39-089-965077 (A.S.); \\ +39-019-5474668 (R.M.)
}

Citation: Santoro, A.; Mele, E.;

Marino, M.; Viggiano, A.; Nori, S.L.; Meccariello, R. The Complex Interplay between Endocannabinoid System and the Estrogen System in Central Nervous System and Periphery. Int. J. Mol. Sci. 2021, 22, 972. https://doi.org/10.3390/ ijms22020972

Received: 20 December 2020

Accepted: 13 January 2021

Published: 19 January 2021

Publisher's Note: MDPI stays neutral with regard to jurisdictional claims in published maps and institutional affiliations.

Copyright: (c) 2021 by the authors. Licensee MDPI, Basel, Switzerland. This article is an open access article distributed under the terms and conditions of the Creative Commons Attribution (CC BY) license (https:// creativecommons.org/licenses/by/ $4.0 /)$.

\begin{abstract}
The endocannabinoid system (ECS) is a lipid cell signaling system involved in the physiology and homeostasis of the brain and peripheral tissues. Synaptic plasticity, neuroendocrine functions, reproduction, and immune response among others all require the activity of functional ECS, with the onset of disease in case of ECS impairment. Estrogens, classically considered as female steroid hormones, regulate growth, differentiation, and many other functions in a broad range of target tissues and both sexes through the activation of nuclear and membrane estrogen receptors (ERs), which leads to genomic and non-genomic cell responses. Since ECS function overlaps or integrates with many other cell signaling systems, this review aims at updating the knowledge about the possible crosstalk between ECS and estrogen system (ES) at both central and peripheral level, with focuses on the central nervous system, reproduction, and cancer.
\end{abstract}

Keywords: endocannabinoid system; estrogens; central nervous system; reproduction; cancer

\section{Introduction}

The endocannabinoid system (ECS) is a lipid cell signaling system required to maintain homeostasis. It is expressed from lower organisms to humans (except for insects) and this suggests a pivotal role of ECS for essential functions in animals [1-3]. The ECS system takes its name from the Cannabis sativa plant since some phytocannabinoids, including the main psychoactive principle $\Delta^{9}$ — tetrahydrocannabinol $\left(\Delta^{9}-\mathrm{THC}\right)$, can mimic the effects of endocannabinoids by binding to their endogenous receptors [4]. From its discovery in 1964 [5], several studies tried to elucidate the pathophysiological role of ECS and the knowledge on this system increased enormously. However, studies have revealed a complex ECS function that overlaps or cooperates with many other cell signaling systems making it difficult to establish the exact role of the ECS in human cells, tissues, and organs. From this hand, the importance of the possible interactions between ECS and estrogen system (ES) emerged [6-9]. Therefore, this review aims to update the knowledge about the ECS and the ES cross-talk at both the central and peripheral levels.

\section{The ECS System}

The ECS is a ubiquitous cell signaling system that is involved in a wide range of physiological processes and pathological conditions including homeostasis, reproduction, cancer, inflammation, cardiovascular disease, and neurodegeneration [10-13]. It is constituted by lipid messengers named endogenous cannabinoids or endocannabinoids, the cannabinoid (CB) receptors, and the enzymes catalyzing their biosynthesis and degradation [14]. The known endocannabinoids are N-arachidonoylethanolamide (anandamide, 
AEA), 2-arachidonoylglycerol (2-AG), 2-arachidonyl glyceryl ether (noladine, 2-AGE), virodhamine (O-arachidonoyl ethanolamine), and $\mathrm{N}$-arachidonoyl-dopamine (NADA).

The first identified endocannabinoid was AEA that was isolated in the pig brain in 1992 immediately after the discovery of the CB1 receptor [15]. It is an amide derivative of arachidonic acid but conversely to many other neurotransmitters that are stored in synaptic vesicles, AEA (and 2-AG) are produced "on-demand" by neurons from the cleavage of membrane phospholipid precursors, following the depolarization of cell membrane and intracellular increase in calcium levels $\left(\mathrm{Ca}^{2+}\right)$ [4]. However, recently an adiposomic localization of AEA has been reported in different cell types highlighting the possibility of this endocannabinoid to be stored in internal organelles [16]. Once produced, AEA or 2-AG can be released from the pre- or post-synaptic membrane, in the intersynaptic space; then, they travel in a retrograde direction to bind $\mathrm{CB}$ receptors on presynaptic terminals [4]. Activation of $\mathrm{CB}$ receptors involves the inhibition of the activity adenylate cyclase, with lower production of the second cAMP messenger, ultimately leading to a hyperpolarization of the cell membranes and activation or inhibition of specific ion channels and signaling pathways that are capable to change intracellular metabolism. Thereafter, the removal of AEA and 2-AG from the presynaptic space takes place by a selective reuptake process mediated by a membrane transporter or by passive diffusion across the membrane. Once inside the cell, AEA and 2-AG are rapidly hydrolyzed by the fatty acid amide hydrolase (FAAH) and monoacylglycerol lipase (MAGL) enzymes with their consequent deactivation (see References $[4,16]$ for recent reviews). Figure 1 summarizes the retrograde action of endocannabinoids and their uptake and hydrolysis in neurons.

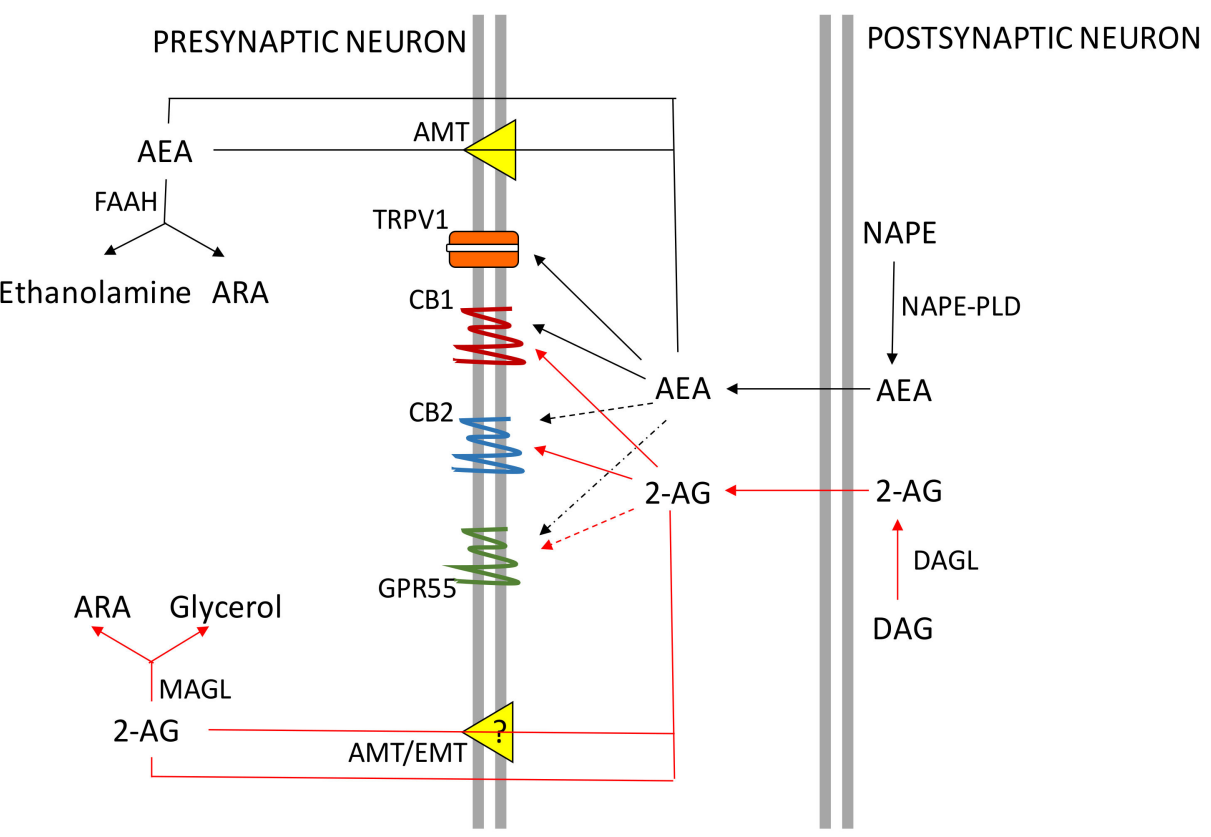

Figure 1. Schematic representation of the ECS in neurons. 2-AG: 2-arachidonoylglycerol; AEA: anandamide ( $\mathrm{N}$-arachidonoylethanolamide); ARA: Arachidonic acid; ATM: AEA membrane transporter; CB1: Type 1 cannabinoid receptor; CB2: Type 2 cannabinoid receptor; DAG: diacylglycerol; DAGL: DAG lipase ETM: endocannabinoid membrane transporter; FAAH; fatty acid amide hydrolase; GPR55: orphan G protein-coupled receptor 55; MAGL: monoacylglycerol lipase; NAPE: $\mathrm{N}$-acylphosphatidylethanolamide; NAPE-PLD: NAPE-phospholipase D; TRPV1: transient receptor potential cation channel subfamily $\mathrm{V}$ member 1 . 


\section{CB Receptors Expression in the Central Nervous System (CNS) and Peripheral Organs}

Endocannabinoids exert their functions essentially by binding to CB1 and CB2 receptors. However, the evidence pointed to the existence of other receptors such as transient receptor potential cation channel subfamily V member 1 (TRPV1), the "orphan" receptors coupled to the G protein GPR55 and GPR119, and peroxisome proliferator-activated receptors (PPARs) that are capable of binding both centrally and peripherally endocannabinoids or endocannabinoid-like compounds $[4,16]$. The CB1 and CB2 receptors are encoded by CNR1 and CNR2 genes, respectively, and belong to the family of G protein-coupled receptors (GPCR) superfamily. They are seven transmembrane domain receptors bearing both extracellular amino terminal and carbonyl terminal intracellular domains [17]. Of note, CB1 and CB2 receptors share a significant homology however they differ in their function and specificity [18]. The CB1 receptor is most abundant in the CNS and is widely expressed in several brain areas with the highest concentration in regions associated with cognition, movement, and emotional behavior like the amygdala, hippocampus, septum, brain cortex, globus pallidus, substantia nigra, cerebellum, and putamen [19]. The CB1 receptor is localized preferentially in presynaptic glutamatergic and $\gamma$-aminobutyric (GABA) acid axon terminals; however, in the hippocampus, the CB1 receptor is located mainly in GABA-ergic, inhibitory interneurons and is present at lower concentrations in the hippocampal glutamatergic axon terminals [20]. Additionally, the CB1 receptor is present in the periphery both on sensory nerve fibers, the autonomic nervous system $[18,21]$ and, among others, in breast, colon, and testis where it modulates cell proliferation, cell cycle progression, and cell differentiation [6,22-24].

The CB2 receptor has been found mainly outside the CNS and is particularly associated with immune tissues and organs, such as the spleen, the thymus, tonsils, and bone marrow, and is expressed in circulating immune cell populations in which it exhibits immunomodulatory functions [18]. However, in recent years CB2 receptors mRNA expression has been found at low concentrations in CNS neurons of the brainstem, cerebellum, and cortex $[25,26]$ as well as in the internal and the external segments of the globus pallidus of the non-human primates [27], in human substantia nigra [28,29], in hippocampal glutamatergic neurons, [30] and dopaminergic neurons of the ventral tegmental area [31]. These findings suggest an important role of the $\mathrm{CB} 2$ receptor in the brain and have promoted investigations on the CB2 receptor in neural functions such as pain, movement, memory, and learning. On the other hand, upregulation of the $\mathrm{CB} 2$ receptor has been linked to various insults, such as chronic pain, neuroinflammation, and stroke [32,33]. Morgan et al., 2009 [34] have documented the presence of a functional expression of the CB2 receptor at the synapse level in the medial entorhinal area of the rat. In fact, they found that the pharmacological blockade of the CB1 receptor was not able to inhibit the effects induced by 2-AG on neurons, whereas CB2 receptor agonist JWH-133 suppressed 2-AG-induced inhibition of GABAergic neurons and this effect could be reversed by the CB2 receptor inverse agonist AM-630 suggesting a role for this receptor in neurotransmission [34]. According to the $\mathrm{CB} 2$ receptor role in the immune system, its expression has been found also in microglia, the only CNS cell type deriving from hematopoietic stem cells [35]. The role of the CB2 receptor in microglia is not fully understood, however, several studies evidenced a CB2 receptor up-regulation in activated microglia following pathological conditions such as inflammation, Alzheimer's disease, and dementia [36-39]. Due to the complex function played by microglia either in neuronal proliferation and differentiation during CNS development or in neuronal functions and senescence in adults [35], these findings highlight the pivotal role that this receptor holds within the brain.

\section{The ES}

Estrogens are steroid hormones regulating growth, differentiation, and many other functions in a broad range of target tissues. Classically, the biological effects of estrogens are mediated through their interaction with estrogen receptor alpha (ER $\alpha)$ and beta $(E R \beta)$, which are members of the large superfamily of nuclear receptors. The ER dimers move 
from the cytoplasm into the nucleus and bind specific estrogen response elements (EREs) on the promoter region of target genes giving rise to defined effects "genomic" [40]. However, about one-third of the genes in humans that are regulated by ERs do not contain ERE-like sequences [41]. In fact, ERs can regulate gene expression also by modulating the function of other classes of transcription factors such as AP-1 through protein-protein interactions in the nucleus and this represents a typical ERE-independent genomic action [42]. Moreover, estrogens can exert rapid effects independently from the activation of RNA and protein synthesis. These actions are known as "nongenomic" effects and are probably mediated through plasma membrane-associated forms of ERs $m E R \alpha$ and $m E R \beta$, the G proteincoupled receptor GPER1/GPER30, and ER-X [43]. $m E R \alpha$ and $m E R \beta$ derive from the same transcripts of ER $\alpha$ and $E R \beta$ and have been found in several peripheral and central tissues where they are responsible for rapid estrogen signaling [44,45]. Conversely, GPER30 is a transmembrane $\mathrm{G}$ protein-coupled ER-localized both in the plasma membrane and endoplasmic reticulum of several brain areas including the cortex, hippocampus, and striatum, and also expressed in liver, male and female reproductive tract, and in vascular smooth muscle cells [44]. Its activation protects against the neurotoxicity induced by Nmethyl-d-aspartate (NMDA) exposure in cortical neurons and glutamate injuries in the retina [43]. Intriguingly, ER-X has been found in mice brain and uterus; it can interact with both $17 \alpha$ estradiol and $17 \beta$ estradiol, even though its preferred ligand is $17 \alpha$ estradiol. ER-X expression is developmentally regulated probably having an important but yet undiscovered role in both the adult hippocampus and neocortex as well as in the uterus [46]. Indeed, in the brain and the uterus, ER-X has been found during the first postnatal month while it becomes scarcely detectable in the adult, suggesting that it could be implicated either in neuronal cortex differentiation or in prenatal sexual development [46]. The actions of plasma membrane ERs are frequently associated with the activation of various protein kinase cascades, however, ER-X stimulation can activate the MAPK/ERK pathway whereas its co-genre receptor ER $\alpha$ seems to be inhibitory $[46,47]$. The most potent estrogen in humans is $17 \beta$ estradiol, but other estrogens such as $17 \alpha$ estradiol estrone and estriol are also present at lower concentrations. The immediate precursor of $17 \beta$ estradiol is testosterone, synthesized by aromatizing ring $\mathrm{A}$ in a three-step reaction catalyzed by the aromatase enzyme complex. Circulating estrogens are produced by the adrenal glands, the gonads, and the placenta can affect the physiological processes of many peripheral target tissues. Furthermore, estrogens can readily cross the blood-brain barrier (BBB) and reach the CNS [48]. The CNS can also synthesize steroids which are involved in neurogenesis and synapses plasticity therefore affecting memory and learning $[49,50]$. Interestingly, the steroids, dehydroepiandrosterone (DHEA) and its sulfate ester (DHEAS), pregnenolone, and allopregnanolone have been found in the brain at concentrations higher than in the serum $[48,51,52]$. However, it is believed that neurosteroids and circulating steroids have similar effects in the CNS [53].

\subsection{Estrogens in the CNS and Reproductive Tract}

There is a strong consistency for an anatomical specific expression of ERs in the brain: it is clear that across species, $\mathrm{ER} \alpha, \mathrm{ER} \beta$, and GPER are widely distributed in brain regions that are not necessarily associated with reproductive functions. Gonadal hormones affect the nervous system in ways that extend beyond their capacity to regulate gonadotropin and prolactin (PRL) production. Estrogens and androgens have been reported to affect verbal fluency, performance on spatial tasks, and to affect the coordination of movement in animals [54-57]. Immunohistochemical staining reveals the presence of steroidogenic proteins including P450(17 $\alpha$ ) and P450 aromatase (also known as P450arom or Cyp19) and steroidogenic acute regulatory protein (StAR) in pyramidal neurons and granule cells of the Dentate gyrus (DG) of adult [58-63] and developmental hippocampus [64-67]. Interestingly, the synthesis of sex steroids by cytochrome P450(17 $\alpha$ ) and P450arom occurs also at the synaptic level suggesting that pyramidal neurons and granule neurons are equipped with complete steroidogenic systems which catalyze the conversion of choles- 
terol to pregnenolone (PREG), DHEA, and estradiol [61,67-69]. The synaptic synthesis of sex steroids (synaptocrine mechanism) proceeds through the first step of glutamate release from the presynapse inducing a $\mathrm{Ca}^{2+}$ influx through the NMDA receptors. The $\mathrm{Ca}^{2+}$ influx drives StAR to transport cholesterol into the mitochondria, where the cytochrome P450 monooxygenase (P450scc) converts cholesterol to PREG. This synaptocrine mechanism highlights another mechanism of estrogen and androgen synthesis in addition to the classical microsomal synthesis of sex steroids in peripheral tissues (References [70-72], for reviews). At the periphery, the activity of Cyp19, the enzyme that locally catalyzes the demethylation of androgens' carbon 19, producing phenolic 18-carbon estrogens is found in several human tissues and cells, including ovarian granulosa cells, the placental syncytiotrophoblast, testis, bone, skin fibroblasts and adipose tissue [73,74].

In the gonads, the production of sex steroids is centrally directed by the hypothalamic gonadotropin-releasing hormone (GnRH) (see Section 5.1 for further details). In the ovary, the 2-cell 2-gonadotophin process is responsible for estradiol production. In fact, during follicle maturation theca cells which are responsive to pituitary luteinizing hormone (LH), produce androgens (predominantly androstenedione and testosterone) that diffuse along the basal lamina of the follicle to reach the Follicle Stimulating Hormone (FSH)-responsive granulosa cells possessing Cyp19 activity [75].

Classically considered as a female hormone, demonstrations of estrogen synthesis in the testis and high concentrations of $17 \beta$-estradiol in rete testis fluid together with the extensive-expression of ERs within the male reproductive tract from the neonatal period to adulthood have been provided [74]. Key roles in male reproduction with involvement in gametogenesis, sperm maturation, and the developmental process of the male reproductive tract have been reported [74,76]. Despite these observations, the gonadal source of estrogen in testis is still debated. In fact, interstitial Leydig cells are the archetype cell previously accepted as the sole estrogen source in adult testis, but several authors suggest Cyp19 activity also in the germinal epithelium [74].

\subsection{Different Functions of ES in Male and Female CNS}

There is mounting evidence that estrogens may have opposite effects in male and female brains principally due to differences in brain organization. The developing brain expresses high levels of ERs and estradiol mediated cellular end-points including morphometry of neurons and astrocytes, the promotion or the inhibition of apoptosis and synaptogenesis in different brain regions [77]. For example, estradiol has opposite effects on several brain areas in males, being simultaneously capable of promoting either the apoptosis in a critical region for female ovulation like the anteroventral periventricular (AVPV) nucleus of the hypothalamus and neurite outgrowth and cell survival in the bed nucleus of the stria terminalis and medial amygdala [78].

Sexual differentiation of the brain requires the activity of Cyp19 and ER $\alpha$ signaling within the hypothalamus to drive the maturation of GnRH neurons and the regulation of sexual behavior through epigenetic mechanisms [73]; consistently, epigenetic modulation of the process by exogenous factors like the exposure to chemicals that exhibit endocrinedisrupting activity has been reported [79]. Therefore, transient exposure to estradiol during critical developmental periods may induce epigenetic changes in the chromatin state of gene regulatory elements within different brain areas, leading to sex-specific differences in both gene expression and transcriptional response to later environmental cues [79].

Sex-specific differences in brain organization are critical for the development of therapies for the treatment of brain disorders that differentially affect men and women [70]. In clinical cases with inactivating mutations in the CYP19 gene, several physiological disturbances have been identified in men, including skeletal, metabolic, and reproductive impairments [80-82]. Studies in aromatase knockout (ArKO) mice generally recapitulate these sequelae in peripheral physiology and, in addition, reveal important functions of estrogens in both male and female brains, thereby highlighting the ubiquitous distribution and function of the aromatase enzyme in peripheral and central tissues. 
In the adult brain, the highest levels of aromatase activity have found in the hypothalamus of all species studied, especially within the preoptic area (POA) and ventromedial nucleus (VMN), where the enzyme is regulated by gonadal steroids and found at higher levels in males than in females [83]. Apart from the hypothalamus, significant levels of aromatase are also found in other brain regions, including the amygdala, hippocampus, midbrain, and cortical regions in rodents, nonhuman primates, and humans, where its expression is steroid-independent and not significantly different in males and females. It is also known that central actions of estrogens may occur via ER-independent mechanisms, which would persist in ER-null mice. Therefore, since the ArKO mice lack the classic ability to synthesize both peripheral and central estrogens, they have provided insights into the CNS roles of estrogens. These include the intriguing observations that in the absence of estrogen synthesis, apoptosis of dopaminergic neurons occurs spontaneously in the adult male, not female, hypothalamus, whereas apoptosis of pyramidal neurons in the frontal cortex occurs spontaneously in the adult female, but not male, brain. This highlights a notable sex dimorphism in the requirement and/or the ability of estrogen to maintain specific neuronal populations in different brain regions. Although the underlying mechanisms and the functional consequences of these morphological changes are unknown, sex- and age-specific behavioral deficits have been identified in ArKO mice [84,85] and support the concept that estrogens play a sexually dimorphic role in the CNS.

Recent data suggest that sexually differentiated intracellular signaling pathways may represent a further mechanism underlying sex-specific responses to estradiol in the brain. In the POA and the VMN, the numbers of cells expressing phosphorylated (activated) cAMP response element-binding protein (CREB) were significantly increased within minutes of treating gonadectomized female mice with estradiol, but this effect was not seen in males [86]. As phosphorylation of CREB is a necessary step in the estrogen-dependent generation of new dendritic spines (at least in cultured hippocampal neurons) [87], sex differences in this signaling mechanism may account for sex-specific effects of estradiol on spine density in the VMN.

Another difference is about synapse density. Estrogens regulate synapse density in the adult rat hypothalamic ventromedial nucleus that differs between males and females [88-90]. This discovery led to the finding that the ovarian cycle regulates cyclic synaptogenesis on excitatory spines in hippocampal CA1 pyramidal neurons in female but not in male rats [91,92]. Synaptogenesis is cyclic, and fluctuations in synapse density occur throughout the estrous cycle of the female rat. Male rats show much less estrogen-induced synapse formation unless they are treated at birth with an aromatase inhibitor [70].

\section{ECS and ES Interactions in the CNS}

The interplay between ECS and ES in the CNS has been little investigated. Few studies demonstrated that the modulation of ECS is involved in the mechanisms of neuroprotection afforded by acute administration of pharmacological doses of estrogen in male rats [93]. Authors, aiming to evaluate the effect of middle cerebral artery occlusion (MCAo)-induced brain insult on AEA regional brain level and receptor binding, found that an intraperitoneal dose of $17 \beta$ estradiol $(0.20 \mathrm{mg} / \mathrm{kg})$ could reverse the endogenous increase of AEA in ischemic striatum. Moreover, brain ischemia did not alter CB receptor expression whereas $17 \beta$ estradiol pre-treatment resulted in a $45 \%$ reduction of CB1 receptor binding in the striatum. The treatment with $17 \beta$ estradiol also modulated Nacyl-phosphatidylethanolamine-hydrolyzing phospholipase D (NAPE-PLD) and FAAH expression and activity, suggesting that the hormone could have a neuroprotective effect by reducing endogenous cannabinoids levels and their ability to induce CB1 receptormediated response [93]. FAAH modulation by estrogens was corroborated in studies of Hill and co-workers (2007) [94] who analyzed the mechanisms by which estrogens elicit anxiolytic and antidepressant-like effects. They investigated the ability of estrogens to modulate the ECS in ovariectomized rats. Results showed that both the pharmacological inhibition of CB1 receptor and the administration of the FAAH inhibitor URB597 were 
able to reverse the significant increase in open arm entries in the elevated plus-maze (EPM) test and time spent in the center quadrant of the open field test (OFT) following $17 \beta$ estradiol treatment [94]. These findings demonstrated that estrogen may produce changes in emotional behavior by modulating ECS activity mainly through FAAH inhibition. Finally, some studies demonstrated that pregnenolone, the inactive precursor of all steroid hormones, acting as a signaling-specific inhibitor of the CB1 receptor, reduces the toxicity of $\Delta^{9}$-THC [95], proposing that ECS could be a target for the development of neurosteroidogenic drugs [96]. The above data suggest that estrogens can modulate directly ECS in the CNS, however, studies are still few and inconclusive. In view of the presence of the $\mathrm{CB} 2$ receptor and the different distribution and concentration of the $\mathrm{CB}$ receptors in the brain, it would be desirable that studies focus on both $\mathrm{CB}$ receptors expression and activity and better investigate the role of endocannabinoids degrading enzymes following estrogen treatments. This could improve the understanding of neurodegeneration and neuroinflammation processes opening new perspectives in drug development.

\section{ECS, Estrogens, and Reproduction}

Reproduction, the process that leads to the production of gametes, is strictly controlled by the activity of the hypothalamic gonadotropin-releasing hormone $(\mathrm{GnRH})$, a decapeptide released in a pulsatile manner within the hypophyseal portal system to stimulate the adenohypophysis to release in the main circulation the pituitary gonadotropins (Luteinizing hormone (LH) and Follicle Stimulating Hormone (FSH)). FSH and LH reach the gonads which in turn produces sex steroids to sustain spermatogenesis in males, follicle development, oocyte maturation, and endometrium receptivity to fertilized oocytes in females [97,98]. Notably, in males testosterone exerts negative feedback on GnRH secretion; in females, estradiol exerts homeostatic, negative feedback on GnRH secretion, but at the end of the follicular phase, the rise in estradiol levels causes the switch into a positive feedback that sustains the GnRH peak and LH surge responsible for ovulation [99] (Figure 2).
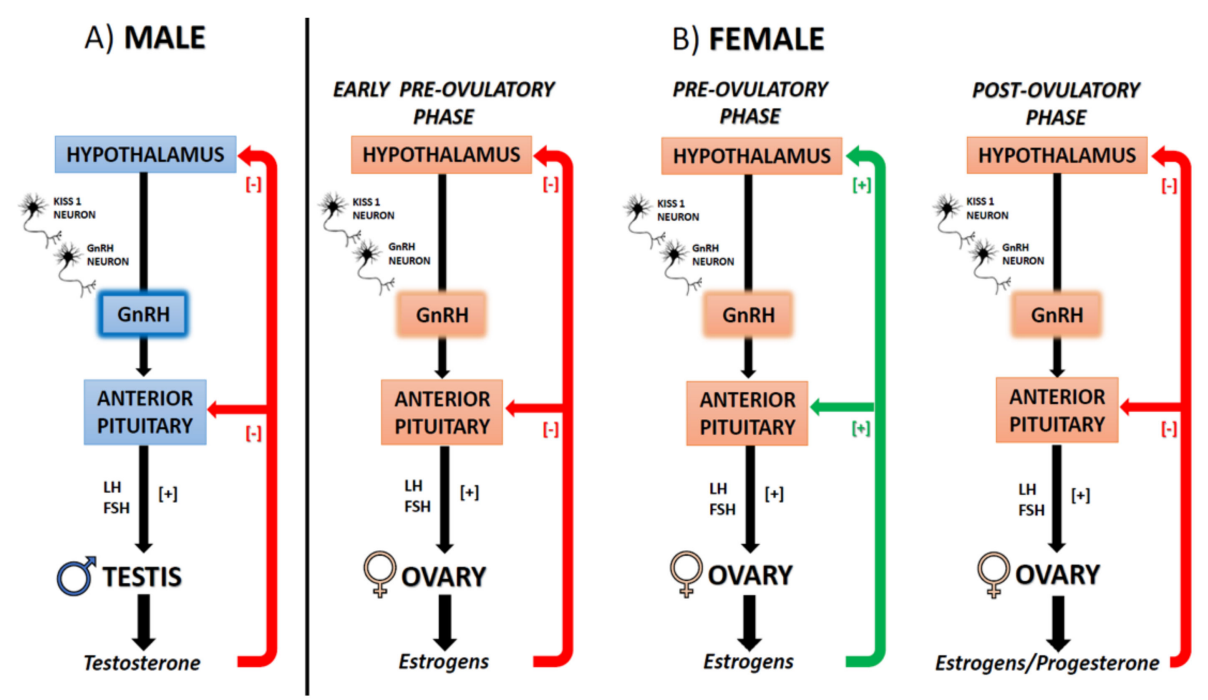

Figure 2. Schematic representation of the hypothalamus-pituitary gonad (HPG) axis in mammals. (A) Male (B) Female at different phases of the ovulatory cycle. Gonadotropin-releasing hormone $(\mathrm{GnRH})$; Luteinizing hormone (LH); Follicle Stimulating Hormone (FSH).

However, within the male and female reproductive system, nuclear and membrane estradiol signaling exerts fundamental activities resulting critical for proliferative events, but also sperm maturation and transport in males [76], ovarian granulosa cell differentiation, follicle and oocyte growth and development, ovulation, endometrial growth and uterus lining in females [100]. 
In addition, several centrally and peripherally produced modulators, regulate the activity of the hypothalamus-pituitary gonad (HPG) axis and steroid production in response to exogenous environmental cues like diet, stress, or drug addiction, with consequences on gamete quality, fertility rate, and pregnancy $[11,76,79,101-104]$.

ECS both centrally and locally affects the activity of the HPG axis in both sexes. Receptors and metabolic enzymes have been detected within the hypothalamus, anterior pituitary, testis, ovary, and reproductive tract $[105,106]$, and endocannabinoids detected within the gonads, in the reproductive tract and reproductive fluids [105,107]. ECS involvement in the modulation of sex steroid biosynthesis, gamete quality, fertilizing ability, implantation, placentation, and embryo development have been reported [105,106,108-113]. As a consequence, the genetic impairment of the system and its epigenetic modulation by lifestyle may have a deep impact on reproduction and fertility in both sexes with possible trans-generational effects ([104] and References inside).

In general, data from in vivo, in vitro, and clinical studies, have reported that cannabinoids in marijuana (i.e., $\Delta^{9}$-THC) can reduce fertility by disrupting the hypothalamic release of GnRH, leading to reduced levels of LH and sex steroids in both sexes, anovulatory cycles and depressed ovarian follicular maturation in females, impaired spermatogenesis, and sperm functions (e.g., motility, capacitation, and the acrosome reaction) in males [105,108,109,112]. Implantation failure, inhibition of early embryo development, increased incidence of miscarriage, preterm birth, prematurity, and low fetal birth weight are the main consequences of marijuana in animal models and marijuana smoker women [104,113]. Interestingly, steroids influence the deleterious effects of marijuana, with estrogen generally increases and progesterone decreasing sensitivity to marijuana [109].

$\Delta^{9}$-THC, the main bioactive constituent of marijuana has been recognized to possess anti-estrogenic activity due to its ability to up-regulate the nuclear ER $\beta$, disrupting estrogen$\mathrm{ER} \alpha$-signaling, and inhibiting the expression of estradiol/ER $\alpha$-regulated genes in cell lines [114]. Similarly, the CB1 receptor antagonist AM251 up-regulates the expression rate and signaling of epidermal growth factor receptor (EGFR) via a CB1 receptor-independent pathway involving the destabilization of ER related $\alpha(E R R \alpha)$ in PANC-1 and HCT116 cancer cell lines [115].

As for marijuana $/ \Delta^{9}-T H C$, the manipulation of ECS or its genetic impairment have deep consequences on reproduction in animal models, with poor gamete quality, (sub)fertility, gestational and developmental troubles in $\mathrm{Cnr1}^{-/-}, \mathrm{Cnr}^{-I_{-}^{-}}$and $\mathrm{Faah}^{-/-}$mice as reviewed elsewhere $[8,108,116-122]$.

The neuroendocrine axis and the consequences of gametogenesis and gamete quality have been deeply analyzed in male $\mathrm{Cnr}^{-/-} \mathrm{KO}$ mice [8]. Mutant mice display normal pituitary LH content but low serum LH concentration, low testosterone secretion from the testis, and low circulating levels of testosterone and estradiol. The expression levels of GnRHR and FSH $\beta$ subunit were respectively increased and decreased in the pituitary; in the testis low expression of FSH receptor (FSHR) and Cyp19 have been reported; a low number of adult Leydig cells [23] expressing low Cyp19 and normal 3 $\beta$-hydroxysteroid dehydrogenase $(3 \beta-H S D)$ mRNA levels complete this intricate neuroendocrine speech [8]. In parallel, precocious acquisition of sperm motility in the epididymis [123] and poor chromatin quality indices (e.g., high histone content, uncondensed chromatin, DNA damage, elongated nuclear size, impaired disulfide bonds formation) [124-127] have been reported, with estradiol administration capable of restoring histone displacement in spermatids $[124,126]$.

In the female reproductive tract, the expression of some components of the ECS is directly modulated by estrogen. Maia and co-workers recently investigated the estradiol benzoate (EB) and tamoxifen dependent modulation of ECS in ovariectomized rats revealing that the expression of CB1 and CB2 receptors, cyclooxygenase-2 (COX-2), and AEA-metabolic enzymes (i.e., NAPE-PLD, FAAH) were higher in the uterus following EB administration; in parallel, the levels of AEA were higher in plasma, but not in the uterus whereas the production of prostaglandin $(\mathrm{PG}) \mathrm{E}_{2}$ - one of the major products of COX-2were higher in the uterus [128]. 
In human granulosa cell line KGN the expression of a complete ECS comprising receptors, biosynthetic and hydrolyzing enzymes (i.e., the $\mathrm{CB} 1$ receptor, the $\mathrm{CB} 2$ receptor, DAGL, FAAH, GPR55, MAGL, NAPE-PLD, and TRPV1) occurred independently from FSH administration [129] and manipulation of CBs affected Cyp19 expression rate with consequences on estradiol but not progesterone biosynthesis. In addition, receptor-dependent changes in the expression levels of microRNA (miRNA) specifically involved in the activity of granulosa cells like miR-23a, miR-24, miR-181a, and miR-320a have been observed [129], thus revealing the requirement of a functional ECS for appropriate estradiol synthesis by the ovary.

However, the modulation of endocannabinoid tone is always critical in both female and male reproduction $[105,108]$. For instance, reduced fertility in the Faah ${ }^{-/-}$mice is due to persistent or elevated endocannabinoid tone/signaling in testis, epididymis, oviduct/uterus, a situation that impairs the physiological environment critical for successful gametogenesis, sperm maturation, normal development of embryos and oviductal transport and implantation [119,122]. Interestingly, in mammalian and non-mammalian vertebrates FAAH, the main endocannabinoid hydrolyzing enzyme, is expressed in an estradiol dependent manner [130-132]. Accordingly, in mouse primary Sertoli cells, estradiol via the nuclear ER $\beta$ binds two EREs within the FAAH promoter and activates FAAH transcription [132]. An epigenetic mechanism involving the histone demethylase LSD1, that acts decreasing methylation of both DNA at CpG site and histone $\mathrm{H} 3$ at lysine 9, has been reported [128]. Interestingly, the stimulation of $F A A H$ expression causes the increase in FAAH protein activity, decreasing AEA levels, and lastly protecting Sertoli cells from AEA-induced apoptosis [133].

Taken together, a deep interplay links ECS and estrogens to gain successful reproduction. Therefore, in the next sections, we summarize the recent findings related to the ECS-dependent modulation of GnRH and the interplay with estrogens.

\subsection{The ECS-Dependent Modulation of GnRH and the Interplay with Estrogens}

The aforementioned ECS effects on reproduction in both sexes are the result of combined centrally and locally mediated effects. Centrally, the effects of the ECS on the secretion of GnRH and the interplay between ECS and estrogens have been documented with direct and mediated effects $[108,110,111]$, but molecular mechanisms are not clearly understood.

Notably, the CB1 receptor is largely expressed within the hypothalamus in neuronal populations, and ex vivo, in vitro, and in vivo endocannabinoids and phytocannabinoids negatively affects GnRH secretion [108]. At the molecular level, retrograde endocannabinoid signaling via $\mathrm{CB} 1$ receptor affects the neuronal networks and the release of neuromodulators involved in the secretion of GnRH like glutamate and GABA. In particular, 2-AG via CB1 receptor reduces the GABAergic synaptic transmission negatively affecting the hypothalamic release of GnRH in male rodents [134]. In addition, direct effects have been also reported in mammals [134] and in the diencephalon of non-mammalian vertebrates, being CB1 receptor co-localized on a subset of GnRH secreting neurons [134,135]. Interestingly, endocannabinoid involvement in the modulation of negative sex steroid feedback has been recently reported throughout the metestrus phase of the ovarian cycle in female mice [136] and, the requirement of ER $\beta$ and 2-AG/CB1 receptor, but not ER $\alpha$ and GPR30, has been demonstrated in gonad-intact transgenic female mice by means of electrophysiological experiments [136].

The modulation of the HPG axis by environmental cues such as stressors or diet reveals the interplay between different neuronal networks and signaling pathways including the ECS [11]. Reproduction strongly depends on energy homeostasis, especially in females [137] and endocannabinoids are well-known regulators of food intake and gut-brain communications [11,138-140]. The possible interplay between estrogen and cannabinoid signaling has been evaluated in ovariectomized female guinea pigs through the use of the $\mathrm{CB} 1$ receptor agonists WIN 55,212-2, EB, and the specific agonists of $\mathrm{ER} \alpha, \mathrm{ER} \beta, \mathrm{mERs}$, and GPR30 (PPT, DPN, STX, and G-1 respectively). Data revealed that in the arcuate nucleus 
(ARC) of females, estrogens negatively modulate cannabinoid-induced changes in energy balance via genomic and nongenomic mechanisms, with the downstream involvement of protein kinase A and C [141].

In such a context kisspeptins, the cleavage product of the Kiss1 precursor, represents the main gatekeepers of the HPG axis being the major upstream modulators of GnRH secreting neurons at puberty onset, a mediator of sex-steroid positive/negative feedback mechanisms, peripheral modulators of gonad physiology in both sexes and biosensors of metabolic status therefore subjected to epigenetic modulation [76,98,102,142,143]. Currently, the possible link between kisspeptin system and ECS has been investigated in mammals following stress, revealing that in male rats $1 \mathrm{~h}$ immobilization stress resulted in a decrease in the serum LH concentration and a drop in kiss1 expression in the medial $\mathrm{POA}$, and to some extent the ARC, key hypothalamic regions that regulate GnRH release. Central administration of the CB1 receptor antagonist AM251 completely reversed this effect confirming CB1 receptor involvement [144].

Recently, a molecular mechanism involving both the kisspeptin system and FAAH has been suggested in the anuran amphibian, the frog Pelophylax esculentus, a seasonal breeder with a complete, well-characterized ECS $[145,146]$ involved in the central and local control of reproduction with effects on steroid biosynthesis and sperm maturation [131,135,147-151]. As for mammals, in this animal model AEA via CB1 receptor centrally impairs the hypothalamic activity of the GnRH system [135], which in the frog comprises two molecular forms (GnRH1 and GnRH2) as ligands and three receptors [148], thus centrally modulating steroid biosynthesis [150]. As reported by Ciaramella et al., in vivo AEA treatment had different outcomes on the HPG axis in frog: (i) decreased the expression levels of Kiss1 and Kiss1R protein and GnRHs and GnRHRs mRNA in brain and testis; (ii) impaired the expression of key steroidogenesis enzymes (i.e., Cyp17 and $3 \beta-H S D$ ) causing a drop in intratesticular testosterone level; (iii) increased the expression of Cyp19, causing the increase of intratesticular estradiol levels, and the estradiol dependent expression of FAAH, [131]. Interestingly, the kisspeptin system not only is the major upstream modulator of $\mathrm{GnRH}$, but it is also involved in sex steroid feedback mechanisms [98], and as both ECS [149] and GnRH system [152], is an intratesticular modulator of spermatogenesis [142,153-155] with functions related to Leydig cells activity, spermatogenesis progression $[142,153,154]$ and a dose-dependent suggestive role in the balance of estradiol and testosterone levels [155]. To discriminate between centrally mediated and direct intragonadic effects, ex vivo incubations of the testis with $\mathrm{AEA} \pm$ rimonabant (SR141716), the antagonist/inverse agonist of $\mathrm{CB} 1$ receptor were carried out, revealing direct $\mathrm{CB} 1$-mediated effects on FAAH, Cyp19, and GnRH system [131,149]. Since the AEA inductive effects on FAAH, the possible involvement of estradiol signaling were assayed incubating frog testis with ICI182-780-a potent ER inhibitor and therefore stimulating with AEA. The preliminary administration of ICI182-780 locked any positive effects of AEA on FAAH expression, providing evidence of combined centrally-mediated, and intratesticular route in the control of sex steroid biosynthesis. Centrally, AEA negatively affects the hypothalamic kisspeptin system to switch off the HPG axis, thus causing testosterone decrease; locally, testosterone is further converted into estradiol, which in turn induces FAAH, indicating the existence of a fine regulatory loop in the modulation of AEA tone (Figure 3). 


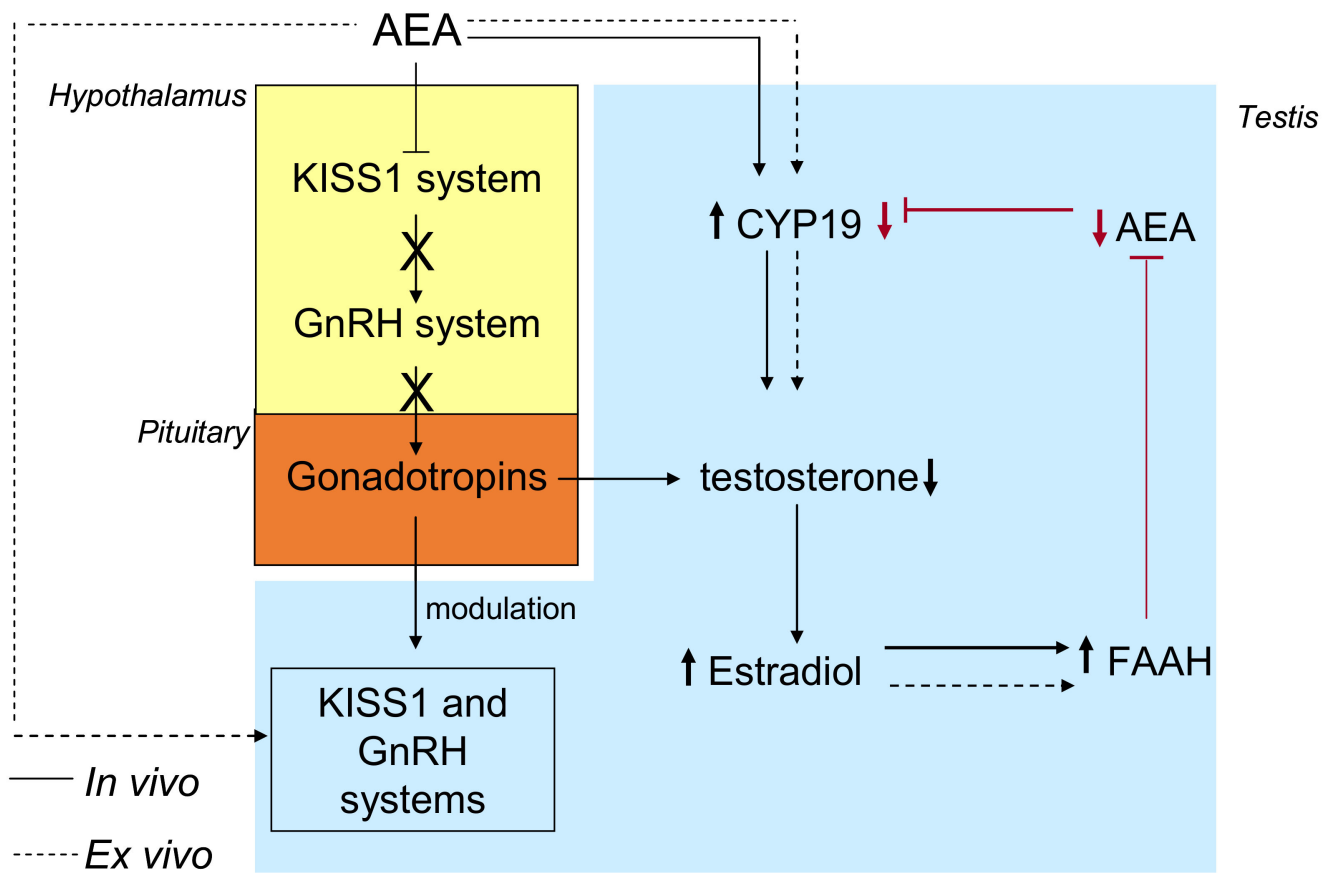

Figure 3. Centrally-mediated, and intratesticular mechanisms in the control of sex steroid biosynthesis through the modulation of FAAH in the frog. Black lines: centrally mediated effects of AEA; dotted black lines: intratesticular effects of AEA; red lines: the possible regulatory feedback loop on AEA tone.

\section{ES and ECS Modulation by Estrogens-Like Substances Affecting CNS and Gonads}

Several natural and synthetic pseudoestrogens including compounds like phytoestrogens, pesticides, parabens, and plasticizers among the others, exhibit estrogenic or antiestrogenic properties and thus are capable of interfering with the physiological signaling of steroids, with consequences on endocrine functions at the central and peripheral level and long-time pleiotropic effects on exposed organisms [156-158]. The majority of harmful effects of endocrine disruptor chemicals (EDCs) have been attributed to molecular mechanisms mediated by nuclear receptors, however recent data support the hypothesis that EDCs can act also through other receptors including the activity of pregnane $X$ receptor (PXR), ERR $\gamma$, thyroid receptor (TRs), retinoid X receptors (RXRs), PPAR $\alpha$, or PPAR $\gamma$ [159].

Substances like Bisphenol A (BPA, 2,2-bis (4-hydroxyphenyl) propane), dibutylphthalate (DBP), bis-(2-ethylhexyl)-phthalate (DEHP) or perfluorinated compounds (PFCs) are EDCs worldwide diffused as an environmental contaminant and are commonly used in the production of daily use goods including food and drink packaging [102,160-162]. In the last year, particular attention has been devoted to BPA, a plasticized largely used for the production of epoxy resins and polycarbonate plastics that is capable of interfering in the endocrine system with main outcomes on reproductive health and the possibility of trans-generation epigenetic inheritance in the offspring [76,79,102]. Currently, oral exposure by ingestion of contaminated foods and drinks represents the major exposure route [102,160], but this compound accumulates in biological tissues and its metabolites are excreted in biological fluids [160]. Furthermore, it crosses both the placental barrier and blood-brain barrier interfering in developmental processes [163,164]. In line with this, we have recently shown that rat offspring exposed to BPA, first via the placenta and during lactation and drinking water later, induced astrocytosis and DNA damage in the hippocampus by modulating the normal expression of ER $\alpha$ [165]. We also found that BPA altered the first round of spermatogenesis with impairment of blood-testis barrier, reactive oxygen species production, and DNA damage [166], strongly suggesting that this EDC can affect both CNS and gonad development and differentiation. As a consequence, gestational 
and neonatal phase, childhood and adolescence represent the main exposure windows critical for health $[79,102]$.

Another class of EDCs widely diffused in the environment both as natural products derived from plants and bacteria or synthesized industrially are parabens [158]. They are used as preservatives to prolong the shelf life of cosmetics, personal care, and food and have been documented to interfere with both androgen and estrogen levels by reducing Cyp19a1 [167]. Indeed, studies revealed that higher urine levels of methylparaben (MeP) and propylparaben $(\mathrm{PrP})$ reduced couple fecundity [168] and PrP influenced negatively follicle reserve and ovarian ageing in women [169]. Results on parabens effects in CNS are quite scanty but some authors reported memory and learning deficits in BuP-treated rats suggesting that $\mathrm{BuP}$ might induce neurodevelopmental disorders [170]. On the contrary, Lara-Valderrábano et al., (2017) [171] observed that PrP suppressed the epileptiform activity of CA1 pyramidal neurons in vitro supporting the beneficial effects of this paraben in the management of some CNS diseases. Interestingly, parabens have been shown to interact also with ECS inhibiting FAAH activity, activating CB1 receptor, and PPAR $\gamma$ with the consequence of promoting adipocyte differentiation [172].

Data from fish recently revealed changes in the expression rate of genes involved in the metabolism of endocannabinoids or in endocannabinoid signaling in both liver and brain following the dietary exposure to BPA, diethylene glycol dibenzoate (DEGB), diisononyl phthalate (DiNP), or nonylphenol (4NP) with altered levels of endocannabinoids, and endocannabinoid-like mediators or altered expression rate of ECS components [173-176]. Interestingly, DEGB acts as an agonist of PPAR $\alpha$ to stimulate key lipolytic genes and simultaneously down-regulates the genes encoding for endocannabinoid metabolic enzyme in the liver of sea bream [175]. Based on the findings that EDCs can target PPAR $\alpha$ and $\operatorname{PPAR} \gamma$, it is conceivable that EDCs could promote developmental, reproductive, and neurological diseases in humans by interfering with the physiological functions of ECS and ES and their complex interplay. In 1-year-old zebrafish environmental BPA exposure altered the intragonadal levels of endocannabinoids and increased the expression of liver vitellogenin in both sexes. Specific changes in the gonads were also observed. In fact, in males, BPA increased the gonadosomatic index (GSI) and reduced the testicular area normally reserved to spermatogonia; in females, it increased the percentage of vitellogenic oocytes in the ovaries [177].

Similarly, in the male gilthead sea bream (Sparus aurata) fed with low and high concentrations of BPA ( 4 and $4000 \mu \mathrm{g} / \mathrm{kg}$ body weight respectively) for 21 days during the reproductive season, high exposure dose increased GSI, impaired sperm motility, increased testosterone level, reduced 11-ketotestosterone levels in plasma with both low and high doses significantly decreasing the intratesticular levels of endocannabinoids (AEA, 2-AG) and endocannabinoid-like compounds [i.e., palmitoylethanolamide (PEA) and oleoylethanolamine (OEA)] [178] with a parallel increase in FAAH activity. At the molecular level, the expression rate of genes encoding for the CB1 receptor, the CB2 receptor, and TRPV1 proteins were dose-dependently affected but not those encoding for the enzymes NAPE-PLD, FAAH, and DAGL $\alpha$ [178].

As for BPA, in the same animal models also the plasticizer DiNP had a similar effect on endocannabinoid tone and FAAH activity [179], with consequences on gonad physiology and the production of qualitatively good gametes; at molecular levels, specific changes in the expression rate of ECS components have been reported.

Low BPA doses (i.e., $0.5 \mu \mathrm{M}$ for $48 \mathrm{~h}$ ) modulate the ECS components in exposed mouse primary Sertoli cells in parallel to an increase in inhibin B levels; in this system, the BPA dependent effects on inhibin $B$ are further enhanced by the blockade of either CB2 or TRPV1 receptors [180] revealing the involvement of CB2- and TRPV1-dependent signal transduction in the BPA mediated effects.

Recently the effects of BPA on ECS have been evaluated in pregnant women, providing evidence of BPA interference in ECS signaling and hypothesizing that BPA may induce adverse pregnancy outcomes modulating the activity of the ECS [181]. In this study 
liquid chromatography-mass spectrometry (LC-MS)-based plasma metabolomics was performed in pregnant women with known concentrations of free, conjugated, and total BPA. Positive correlations were observed between fatty acid amides and free and total BPA concentrations whereas OEA was positively correlated with conjugated BPA and lysophosphatidylethanolamine (LPE) with free BPA. Interestingly, in vitro study revealed that BPA caused a 15\% inhibition of FAAH activity, therefore resulting in a competitive inhibitor capable of blocking FAAH catalytic residues [181]. Since FAAH activity is critical for regulating both the magnitude and duration of AEA signaling, this study has particular relevance in that BPA exposure may lead to a rise in circulating endocannabinoids, a well-known risk factor for miscarriage.

ECD exposure has been suggested to be a possible cause of the decline in human semen quality observed in the last few decades [182,183], with the possible paternal inheritance of epimutations in the offspring [184-186]. Therefore, the need to reduce chemicals in the environment to safeguard male fertility. Notably, marijuana abuse is considered an exposure to endocrine-disrupting factors mainly due to the estrogenic activity of the phenolic compounds contained in marijuana smoke condensate [187]. Nevertheless, the use of cannabinoids for recreational use interferes in the endogenous endocannabinoid tone with consequences on male fertility [105] and point out the epigenetic risk for the offspring [104]. Therefore, the relationships between sperm quality, endocannabinoid profiles in plasma/semen, xenobiotics (i.e., bisphenol A and S), and phytocannabinoids in urine have been recently evaluated in a cohort of 200 young Swiss men (age range 18-22) [188]. An inverse relationship between sperm motility and AEA concentrations in seminal fluid and OEA levels in blood serum has been found; conversely, PEA levels in semen were positively linked to sperm concentration, whereas in seminal fluid the levels of OEA and PEA — that exhibit antioxidants properties [189]—-were associated with better sperm morphology. The presence of urinary THC-COOH (an inactive metabolite of $\Delta^{9}$-THC), used as an indicator of cannabis consumption, in $n=15$ individuals has been linked to lower concentrations of endocannabinoids in semen and low circulating AEA in blood, suggesting a possible $\Delta^{9}$-THC-mediated negative feedback on AEA production and concentration; by contrast, no correlation was observed between the presence of urinary bisphenols and endocannabinoids [188].

Taken together, the world's widespread distribution of EDCs points out a concrete risk for reproductive health and ECS may represent a target for disease, but also a biochemical marker for the toxicological screening of exposed subjects.

\section{ECS and ES Interactions in the Periphery}

\subsection{Interactions in Blood Cells}

Cardiovascular diseases are the leading cause of death in postmenopausal women in developed countries, suggesting that estrogen deficiency may play a causative role [190]. A positive effect of estrogen on plasma lipids and lipoproteins, endothelium-dependent vasodilation, and intimal hyperplasia has been documented [191] and is thought to contribute to the cardioprotective effects observed in women receiving estrogen replacement therapy. In addition, platelets have a well-established role in the pathogenesis of atherosclerosis and cardiovascular diseases [192]. The mechanisms by which estrogen influences coronary arteries and protects blood vessels against atherosclerotic development remain unclear. Yet, recent evidence suggests that the rapid effect of estrogen on vascular reactivity depends on the activation of surface receptors in endothelial cells [193], followed by endocannabinoid release in analogy with the nongenomic effect of glucocorticoids in the hypothalamuspituitary-adrenal axis. In fact, in human umbilical vein endothelial cells (HUVECs) estrogen has been shown to activate the AEA membrane transporter (AMT) through calcium and nitric oxide (NO)-dependent mechanisms [194]. Estrogen stimulates also AEA synthesis via NAPE-PLD and inhibits nongenomically AEA degradation via FAAH, overall increasing the endogenous level of endothelial AEA. Therefore, released AEA can exert its manifold actions on the cardiovascular system, spanning from vasodilation to modulation of cell mi- 
gration [195]. In addition, AEA was found to inhibit 5-hydroxytryptamine (5-HT) secretion from platelets, whereas estrogen did not [194], thus demonstrating that endocannabinoids can complement the biological activity of steroids.

Also, human T lymphocytes witness an intimate cross-talk between steroid hormones and ECS, with critical implications for human reproduction [196]. In circulating T cells, progesterone up-regulates FAAH, but not CB1 receptors, NAPE-PLD, or AMT, and reduces AEA content [197]. Of interest is the fact that progesterone exerts this effect genomically, i.e., by binding to its intracellular receptor (PR) and thus enhancing the level of the transcription factor Ikaros (Ik); this, in turn, increases FAAH gene expression by binding to a speciespecific sequence in the promoter region [197].

\subsection{Interactions of ECS and ES in Cancer}

The ECS is present in both central and peripheral organs and several findings suggest that endocannabinoids levels, ECS degrading enzyme activity as well as CB1 and CB2 receptor expressions are altered in sex-hormone dependent malignant tissues [198] as summarized in Table 1.

Table 1. ECS modulation and its effects in hormone-dependent cancers.

\begin{tabular}{|c|c|c|c|}
\hline $\begin{array}{l}\text { Hormone-Dependent } \\
\text { Cancer }\end{array}$ & $\begin{array}{c}\text { Type of Study/Experimental } \\
\text { Model }\end{array}$ & Main Results & Reference \\
\hline $\begin{array}{c}\text { Hepatocellular } \\
\text { carcinoma (HCC) }\end{array}$ & $\begin{array}{l}\text { HCC samples from patients at } \\
\text { different stages of carcinogenesis }\end{array}$ & $\begin{array}{l}\text { Overexpression of CB1 and CB2 receptor } \\
\text { mRNA and protein expression levels. }\end{array}$ & [199] \\
\hline \multirow[t]{3}{*}{$\begin{array}{l}\text { Human prostate } \\
\text { cancer (PCC) }\end{array}$} & PRL responsive DU-145 cells & $\begin{array}{l}\text { AEA and 2-AG inhibited PRL-induced } \\
\text { DU-145 cell proliferation. }\end{array}$ & [200] \\
\hline & $\begin{array}{l}\text { AR-positive (LNCaP and 22RV1) } \\
\text { and negative (DU-145 and } \\
\text { PC-3) cells. } \\
\text { Mouse model of xenograft tumor. }\end{array}$ & $\begin{array}{l}\text { AEA and Cannabidiol (CBD) inhibited PCC } \\
\text { cell proliferation and potentiated the effects of } \\
\text { bicalutamide and docetaxel against LNCaP } \\
\text { and DU- } 145 \text { xenograft tumors. }\end{array}$ & {$[201,202]$} \\
\hline & $\begin{array}{l}\text { Human PCC tissues and normal } \\
\text { (healthy) prostate tissues }\end{array}$ & $\begin{array}{l}\text { CB1 receptor and TRPV1 mRNAs and protein } \\
\text { levels were higher in PCC. TRPV1 correlated } \\
\text { with increasing PCC tumor grades, whilst CB1 } \\
\text { receptor levels were not. }\end{array}$ & {$[203,204]$} \\
\hline \multirow[t]{3}{*}{ Breast cancer $(\mathrm{BC})$} & $\begin{array}{l}\text { MMTV-neu mouse model of } \\
\text { ErbB2-driven metastatic } \\
\text { breast cancer }\end{array}$ & $\begin{array}{l}\Delta^{9}-\mathrm{THC}, \text { marijuana and JWH-133 (CB2 } \\
\text { receptor agonist) reduced cancer cell } \\
\text { proliferation, impaired tumor angiogenesis, } \\
\text { and reduced lung metastases. }\end{array}$ & [205] \\
\hline & Human ErbB2 BC samples & $\begin{array}{l}\text { Overexpression of } \mathrm{CB} 2 \text { receptor correlated } \\
\text { with ErbB2 expression. }\end{array}$ & \\
\hline & $\begin{array}{l}\text { MCF-7, MDA-MB231 and EFM-19 } \\
\text { and T47D human BC cells }\end{array}$ & $\begin{array}{l}\text { CB1 receptor stimulation by AEA reduced } \\
\text { adhesion and migration of BC cells and AEA } \\
\text { and 2-AG inhibited the nerve growth factor } \\
\text { (NGF)-; inhibition of PRLr levels via CB1 } \\
\text { receptor modulation of PRL responsive BC } \\
\text { cells. } \\
\text { AEA inhibited epithelial-mesenchymal } \\
\text { transition of BC cells. }\end{array}$ & {$[22,200,206,207]$} \\
\hline $\begin{array}{l}\text { Endometrial cancer } \\
\qquad(\mathrm{EC})\end{array}$ & Hec50co and Ishikawa cells & $\begin{array}{l}\text { eCBs and CBD reduced cell viability inducing } \\
\text { apoptosis. }\end{array}$ & [208] \\
\hline
\end{tabular}


Table 1. Cont.

\begin{tabular}{|c|c|c|c|}
\hline $\begin{array}{l}\text { Hormone-Dependent } \\
\text { Cancer }\end{array}$ & $\begin{array}{c}\text { Type of Study/Experimental } \\
\text { Model }\end{array}$ & Main Results & Reference \\
\hline \multirow[t]{4}{*}{$\begin{array}{l}\text { Colorectal cancer } \\
\text { (CRC) }\end{array}$} & $\begin{array}{l}\text { Azoxymethane (AOM)- and } \\
\text { dextran sulfate sodium } \\
\text { (DSS)-induced CRC } \\
\text { mouse models. } \\
\text { Cnr1-/- and } \\
\text { Cnr1 }{ }^{-/-} / \text {GPR } 55^{-/-} \text {double } \\
\text { knockout mice }\end{array}$ & $\begin{array}{l}\text { The putative GPR } 55 \text { receptor acted as an } \\
\text { oncogene and the CB1 receptor as a tumor } \\
\text { suppressor. }\end{array}$ & [209] \\
\hline & $\begin{array}{l}\text { Caco2, DLD-1, and Sw620 CRC } \\
\text { cell lines; AOM-induced CRC } \\
\text { mouse model }\end{array}$ & $\begin{array}{l}\text { The CB1 receptor antagonist/inverse agonist } \\
\text { SR141716 inhibited cell growth and reduced } \\
\text { precancerous lesions in the mouse colon. } \\
\text { Increased AEA levels also reduced CRC cell } \\
\text { proliferation. The inhibitory effect of AEA was } \\
\text { reached by } 17 \beta \text { estradiol driven up-regulation } \\
\text { of the CB1 receptor. }\end{array}$ & {$[6,210]$} \\
\hline & CRC patients & $\begin{array}{l}\text { Hypermethylation of the CNR1 gene in CRC } \\
\text { patients and upregulation of CB1 receptor in } \\
\text { normal tissues. }\end{array}$ & \\
\hline & $\begin{array}{l}\text { Colon biopsy by patients. CaCo- } 2 \\
\text { and DLD- } 1 \text { cell lines }\end{array}$ & $\begin{array}{l}\text { AEA and 2-AG levels were elevated in } \\
\text { adenomas and CRCs. AEA and 2-AG } \\
\text { treatment inhibited CRC cell proliferation in a } \\
\text { CB1 and CB2 receptors dependent manner. }\end{array}$ & [211] \\
\hline
\end{tabular}

In hepatocellular carcinoma, $\mathrm{CB} 1$ and $\mathrm{CB} 2$ receptor expressions have been shown higher in well-differentiated cancers compared to poorly differentiated ones [199]. Moreover, Caffarell et al., (2010) [205] reported that highly aggressive ErbB2-positive breast cancer showed an upregulation of the CB2 receptor which correlates with ErbB2 expression. In contrast, $\mathrm{CB} 1$ receptor immunoreactivity was detected only in $14 \%$ of the tumors and no correlation was found with ErbB2. In normal mammary tissues, no significant CB1 or CB2 receptor immunoreactivity was detected suggesting that the overexpression of both $\mathrm{CB}$ receptors could be implicated in the development of this type of cancer [205]. However, not only in the canonical estrogen-dependent cancers but also in colon cancer-where the estrogen system has been suggested to play a crucial role in neoplastic transformation and cell proliferation [212,213] — is affected by ECS alterations. Indeed, some authors showed a CB1 receptor mRNA upregulation in normal colon tissues compared to colon cancer samples probably due to the hypermethylation of the CNR1 gene encoding for the CB1 receptor [209]. On the other hand, cannabinoids (particularly $\Delta^{9}$-THC and cannabidiol, CBD) and endocannabinoids like AEA inhibited cancer cell growth and metastasis formation both in vitro and in vivo reviewed in [214-216]. Some evidence also indicated that AEA and 2-AG reduced colon cancer cell proliferation activating the CB1 receptor [215]. Similar results were obtained by the treatment with high pharmacological doses of the CB1 receptor antagonist/inverse agonist SR141716 that was able to inhibit cell proliferation in breast and colon cancer in the last case activating rather than suppressing the CB1 receptor $[210,217]$. From this point of view, the evidence seems to indicate a wide interplay between estrogen hormones and ECS [7]. The first evidence for a control of the ECS on estrogen system was provided by De Petrocellis et al., (1998) [206] and Melck et al., (2000) [200] who showed that AEA treatment was able to inhibit the proliferation of prolactin (PRL)-responsive human breast cancer cells and this effect was mediated by the down-regulation of the PRL receptor. Similar results were obtained by the same group in PRL- responsive human prostate DU145 cancer cells in which the PRL-induced cell growth was potently inhibited by both AEA and 2-AG [200]. Furthermore, Bifulco's group [22,207] found that CB1 receptor stimulation by AEA reduced cell proliferation in both ER-positive and ER-negative breast cancer cells being effective in inhibiting adhesion, migration as well as the epithelial-mesenchymal 
transition during cancer progression [188]. The intriguing effect of ECS stimulation as a cancer suppressor in estrogen-dependent tumors was furtherly investigated starting from the observation that $17 \beta$ estradiol was capable to induce CB1 receptor expression in colon cancer cells [218]. It was shown that the overexpression of the CB1 receptor by $17 \beta$ estradiol in DLD1 and SW620 cells was mediated directly through the activation of the CNR1 gene promoter [6]. The same authors also found that increased levels of AEA either by exogenous administration or by using the FAAH inhibitor URB597 induced ER $\beta$ transcription and expression suggesting that the cross-talk between ECS and ES could control colon cancer cell proliferation [213]. Recently, it has been demonstrated the presence of an active ECS system also in endometrial cancer [219], in fact endogenous cannabinoids and CBD induced a significant reduction in cell viability in both Ishikawa and Hec50co cells by the activation of the apoptosis pathway, instead, $\Delta^{9}$-THC did not cause any effect [208]. CB1 receptor expression upregulation has been observed in prostate cancer tissues [204] and elevated levels of this receptor are associated with cancer severity and outcome [203]. Accordingly, AEA has been found to exhibit antiproliferative effects in LNCaP, DU145, and PC3 prostate cancer cells by acting through cannabinoid CB1 receptor and this led to an inhibition of the EGF-stimulated growth of these cells [201]. However recent studies documented that the cannabinoids CBD was able to reduce androgen receptor (AR)-positive (LNCaP and 22RV1) and AR-negative (DU-145 and PC-3) cells in a CB receptors independent manner [202], suggesting that $\mathrm{CB} 1$ receptor could be the main cannabinoid receptor that regulates the complex carcinogenic steps leading to prostate cancer.

Altogether these results underline a protective role for ECS in steroid-hormonedependent cancers highlighting that the ES can regulate the ECS during tumor development and progression.

Although ECS is abundantly in the CNS and the role of estrogen is documented in brain development and in several physiological processes of the CNS like memory and learning [79,104], until now there is no direct evidence of a possible interplay between ECS and ES in brain cancer. Recent studies found that astrocytomas, the most prevalent type of glioma could be influenced by sex steroid hormones (reviewed in [220]) and high expression of the orphan nuclear ERR $\alpha$ is a marker of poor prognosis in patients with glioma [221]. The Authors demonstrated that ERR $\alpha$ overexpression enhanced cell proliferation and migration of SNB-19, SF-295, A172, T98G, LN229, and LN18 glioma cell lines in vitro and ERR $\alpha$ silencing reduced glioma growth in a xenograft model [221]. On the other hand, recently Wu et al., (2012) [222] investigated ECS levels and expression, in human low grade and high-grade glioma tissues showing that 2-AG levels increased in more malignant glioma (WHO grade III and IV) while CB1 and CB2 receptors expression levels were elevated in human glioma compared to normal tissues [222]. Based on these findings it is conceivable that ECS is related to glioma cancer progression and could cooperate with the estrogen system in controlling human glioma cell proliferation and transformation. Therefore, targeting simultaneously CB and ER receptors could be a therapeutic strategy in the management of brain cancers. Moreover, the fact that ECS and estrogen system activate and share several cell signaling pathways such as the MAPK, ERK 1/2, PI3K, and $C-$ jun $-N$ terminal kinase typically involved in cancer cell proliferation [9] empowers the importance of investigating the simultaneous modulation of these two systems in cancer to develop new pharmacologic approaches.

\section{Closing Remarks}

The interplay between ECS and estrogen is well documented in brain development and several physiological processes of the CNS like memory and learning or the central control of reproduction; the same occurs at the periphery, primarily in the gonads and reproductive tract. Particular interest deserves the estradiol dependent expression of FAAH, the key enzyme in the modulation of endocannabinoid tone and therefore a primary actor in driving endocannabinoid signaling. In this respect, environmental factors like chemicals that mimic estradiol signaling or impaired levels of endogenous estradiol may 
have deep consequences for health, particularly on reproduction and behavior, by means of direct (or indirect) modulation of endocannabinoid signaling. ECS plays a protective role in steroid hormone-dependent tumors, but not in brain cancer. However, ECS may represent a prognostic/diagnostic/therapeutic biomarker for cancer and the simultaneous investigation of ECS and ES system may result useful for the development of pharmacologic approaches, particularly in diseases that show a very different incidence and maybe different features of pathogenesis in both sexes.

Author Contributions: Conceptualization, A.S. and R.M.; writing-original draft preparation, E.M., M.M., A.S., and R.M.; writing—review and editing; A.V. and S.L.N.; supervision, A.S. and R.M. All authors have read and agreed to the published version of the manuscript.

Funding: This research was funded by Miur, Prin 2017 grant number 20175MT5EM, to A.V. and R.M.; FFABR from MIUR and University of Salerno ORSA188304 and ORSA191889 to A.S.

Institutional Review Board Statement: Not applicable.

Informed Consent Statement: Not applicable.

Data Availability Statement: Data sharing not applicable.

Conflicts of Interest: The authors declare no conflict of interest.

\section{References}

1. McPartland, J.M.; Matias, I.; Di Marzo, V.; Glass, M. Evolutionary origins of the endocannabinoid system. Gene 2006, $370,64-74$. [CrossRef] [PubMed]

2. Fasano, S.; Meccariello, R.; Cobellis, G.; Chianese, R.; Cacciola, G.; Chioccarelli, T.; Pierantoni, R. The endocannabinoid system: An ancient signaling involved in the control of male fertility. Ann. N. Y. Acad. Sci. 2009, 1163, 112-124. [CrossRef] [PubMed]

3. Elphick, M.R. The evolution and comparative neurobiology of endocannabinoid signalling. Philos. Trans. R. Soc. Lond. B Biol. Sci. 2012, 367, 3201-3215. [CrossRef] [PubMed]

4. Lu, H.C.; Mackie, K. An Introduction to the Endogenous Cannabinoid System. Biol. Psychiatr. 2016, 79, 516-525. [CrossRef] [PubMed]

5. Gaoni, Y.; Mechoulam, R. Isolation, structure and partial synthesis of an active constituent of hashish. J. Am. Chem. Soc. 1964, 86, 1646-1647. [CrossRef]

6. Proto, M.C.; Gazzerro, P.; Di Croce, L.; Santoro, A.; Malfitano, A.M.; Pisanti, S.; Laezza, C.; Bifulco, M. Interaction of endocannabinoid system and steroid hormones in the control of colon cancer cell growth. J. Cell. Physiol. 2012, 227, 250-258. [CrossRef] [PubMed]

7. Ayakannu, T.; Taylor, A.H.; Marczylo, T.H.; Willets, J.M.; Konje, J.C. The Endocannabinoid System and Sex Steroid Hormonedependent cancers. Int. J. Endocrinol. 2013, 2013, 259676. [CrossRef]

8. Cacciola, G.; Chioccarelli, T.; Fasano, S.; Pierantoni, R.; Cobellis, G. Estrogens and spermiogenesis: New insights from type 1 cannabinoid receptor knockout mice. Int. J. Endocrinol. 2013, 2013, 501350. [CrossRef]

9. Dobovišek, L.; Hojnik, M.; Ferk, P. Overlapping molecular pathways between cannabinoid receptors type 1 and 2 and estrogens/androgens on the periphery and their involvement in the pathogenesis of common diseases (Review). Int. J. Mol. Med. 2016, 38, 1642-1651. [CrossRef]

10. Lipina, C.; Hundal, H.S. The endocannabinoid system: 'NO' longer anonymous in the control of nitrergic signalling? J. Mol. Cell Biol. 2017, 9, 91-103. [CrossRef]

11. Chianese, R.; Coccurello, R.; Viggiano, A.; Scafuro, M.; Fiore, M.; Coppola, G.; Operto, F.F.; Fasano, S.; Layé, S.; Pierantoni, R.; et al. Impact of dietary fat on brain functions. Curr. Neuropharmacol. 2018, 16, 1059-1085. [CrossRef] [PubMed]

12. Meccariello, R. Endocannabinoid System in Health and Disease: Current Situation and Future Perspectives. Int. J. Mol. Sci. 2020, 21, 3549. [CrossRef] [PubMed]

13. Haspula, D.; Clark, M.A. Cannabinoid Receptors: An Update on Cell Signaling, Pathophysiological Roles and Therapeutic Opportunities in Neurological, Cardiovascular, and Inflammatory Diseases. Int. J. Mol. Sci. 2020, 21, 7693. [CrossRef] [PubMed]

14. Bifulco, M.; Santoro, A.; Laezza, C.; Malfitano, A.M. Cannabinoid receptor CB1 antagonists state of the art and challenges. Vitam. Horm. 2009, 81, 159-189. [PubMed]

15. Devane, W.A.; Hanus, L.; Breuer, A.; Pertwee, R.G.; Stevenson, L.A.; Griffin, G.; Gibson, D.; Mandelbaum, A.; Etinger, A.; Mechoulam, R. Isolation and structure of a brain constituent that binds to the cannabinoid receptor. Science 1992, 258, 1946-1949. [CrossRef]

16. Maccarrone, M. Metabolism of the Endocannabinoid Anandamide: Open Questions after 25 Years. Front. Mol. Neurosci. 2017, 10, 166. [CrossRef] 
17. Howlett, A.C.; Barth, F.; Bonner, T.I.; Cabral, G.; Casellas, P.; Devane, W.A.; Felder, C.C.; Herkenham, M.; Mackie, K.; Martin, B.R.; et al. International Union of Pharmacology. XXVII. Classification of cannabinoid receptors. Pharmacol. Rev. 2002, 54, 161-202. [CrossRef]

18. Klein, T.W.; Newton, C.; Larsen, K.; Lu, L.; Perkins, I.; Nong, L.; Friedman, H. The cannabinoid system and immune modulation. J. Leukoc. Biol. 2003, 74, 486-496. [CrossRef]

19. Bialuk, I.; Winnicka, M.M. AM251, cannabinoids receptor ligand, improves recognition memory in rats. Pharmacol. Rep. 2011, 63, 670-679. [CrossRef]

20. Litvin, Y.; Phan, A.; Hill, M.N.; Pfaff, D.W.; McEwen, B.S. CB1 receptor signaling regulates social anxiety and memory. Genes Brain Behav. 2013, 12, 479-489. [CrossRef]

21. Morena, M.; Campolongo, P. The endocannabinoid system: An emotional buffer in the modulation of memory function. Neurobiol. Learn. Mem. 2014, 112, 30-43. [CrossRef] [PubMed]

22. Grimaldi, C.; Pisanti, S.; Laezza, C.; Malfitano, A.M.; Santoro, A.; Vitale, M.; Caruso, M.G.; Notarnicola, M.; Iacuzzo, I.; Portella, G.; et al. Anandamide inhibits adhesion and migration of breast cancer cells. Exp. Cell. Res. 2006, 312, 363-373. [CrossRef] [PubMed]

23. Cacciola, G.; Chioccarelli, T.; Mackie, K.; Meccariello, R.; Ledent, C.; Fasano, S.; Pierantoni, R.; Cobellis, G. Expression of type-1 cannabinoid receptor during rat postnatal testicular development: Possible involvement in adult Leydig cell differentiation. Biol. Reprod. 2008, 79, 758-765. [CrossRef] [PubMed]

24. Barchi, M.; Innocenzi, E.; Giannattasio, T.; Dolci, S.; Rossi, P.; Grimaldi, P. Cannabinoid Receptors Signaling in the Development, Epigenetics, and Tumours of Male Germ Cells. Int. J. Mol. Sci. 2019, 21, 25. [CrossRef] [PubMed]

25. Van Sickle, M.D.; Duncan, M.; Kingsley, P.J.; Mouihate, A.; Urbani, P.; Mackie, K.; Stella, N.; Makriyannis, A.; Piomelli, D.; Davison, J.S.; et al. Identification and functional characterization of brainstem cannabinoid CB2 receptors. Science 2005, 310 329-332. [CrossRef]

26. Rodríguez-Cueto, C.; Benito, C.; Fernández-Ruiz, J.; Romero, J.; Hernández-Gálvez, M.; Gómez-Ruiz, M. Changes in CB(1) and $\mathrm{CB}(2)$ receptors in the post-mortem cerebellum of humans affected by spinocerebellar ataxias. Br. J. Pharmacol. 2014, 171, 1472-1489. [CrossRef]

27. Lanciego, J.L.; Barroso-Chinea, P.; Rico, A.J.; Conte-Perales, L.; Callén, L.; Roda, E.; Gómez-Bautista, V.; López, I.P.; Lluis, C.; Labandeira-García, J.L.; et al. Expression of the mRNA coding the cannabinoid receptor 2 in the pallidal complex of Macaca fascicularis. J. Psychopharmacol. 2011, 25, 97-104. [CrossRef]

28. Fernández-Ruiz, J.; Hernández, M.; Ramos, J.A. Cannabinoid-Dopamine Interaction in the Pathophysiology and Treatment of CNS Disorders. CNS Neurosci. Ther. 2010, 16, 72-91. [CrossRef]

29. Lutz, B. Neurobiology of cannabinoid receptor signalling. Dialogues Clin. Neurosci. 2020, 22, 207-222.

30. Stempel, A.V.; Stumpf, A.; Zhang, H.Y.; Özdoğan, T.; Pannasch, U.; Theis, A.K.; Otte, D.M.; Wojtalla, A.; Rácz, I.; Ponomarenko, A.; et al. Cannabinoid type 2 receptors mediate a cell type-specific plasticity in the hippocampus. Neuron 2016, 90, 795-809. [CrossRef]

31. Zhang, H.Y.; Gao, M.; Shen, H.; Bi, G.H.; Yang, H.J.; Liu, Q.R.; Wu, J.; Gardner, E.L.; Bonci, A.; Xi, Z.X. Expression of functional cannabinoid CB2 receptor in VTA dopamine neurons in rats. Addict. Biol. 2017, 22, 752-765. [CrossRef] [PubMed]

32. Jordan, C.J.; Xi, Z.X. Progress in brain cannabinoid CB2 receptor research: From genes to behavior. Neurosci. Biobehav. Rev. 2019, 98, 208-220. [CrossRef] [PubMed]

33. Yu, S.J.; Reiner, D.; Shen, H.; Wu, K.J.; Liu, Q.R.; Wang, Y. Time-dependent protection of CB2 receptor agonist in stroke. PLoS ONE 2015, 10, e0132487. [CrossRef] [PubMed]

34. Morgan, N.H.; Stanford, I.M.; Woodhall, G.L. Functional CB2 type cannabinoid receptors at CNS synapses. Neuropharmacology 2009, 57, 356-368. [CrossRef] [PubMed]

35. Santoro, A.; Spinelli, C.C.; Martucciello, S.; Nori, S.L.; Capunzo, M.; Puca, A.A.; Ciaglia, E. Innate immunity and cellular senescence: The good and the bad in the developmental and aged brain. J. Leukoc. Biol. 2018, 103, 509-524. [CrossRef] [PubMed]

36. Carlisle, S.J.; Marciano-Cabral, F.; Staab, A.; Ludwick, C.; Cabral, G.A. Differential expression of the CB2 cannabinoid receptor by rodent macrophages and macrophage-like cells in relation to cell activation. Int. Immunopharm. 2002, 2, 69-82. [CrossRef]

37. Benito, C.; Kim, W.K.; Chavarria, I.; Hillard, C.J.; Mackie, K.; Tolon, R.M.; Williams, K.; Romero, J. A glial endogenous cannabinoid system is upregulated in the brains of macaques with simian immunodeficiency virus-induced encephalitis. J. Neurosci. 2005, 25, 2530-2536. [CrossRef]

38. Maresz, K.; Carrier, E.J.; Ponomarev, E.D.; Hillard, C.J.; Dittel, B.N. Modulation of the cannabinoid CB2 receptor in microglial cells in response to inflammatory stimuli. J. Neurochem. 2005, 2, 437-445. [CrossRef]

39. Nephi, S. Cannabinoid and cannabinoid-like receptors in microglia, astrocytes, and astrocytomas. Glia 2010, 58, 1017-1030.

40. Nilsson, S.; Makela, S.; Treuter, E.; Tujague, M.; Thomsen, J.; Andersson, G.; Enmark, E.; Pettersson, K.; Warner, M.; Gustafsson, J.A. Mechanisms of estrogen action. Physiol. Rev. 2001, 81, 1535-1565. [CrossRef]

41. O'Lone, R.; Frith, M.C.; Karlsson, E.K.; Hansen, U. Genomic targets of nuclear estrogen receptors. Mol. Endocrinol. 2004, 18, 1859-1875. [CrossRef] [PubMed]

42. Gottlicher, M.; Heck, S.; Herrlich, P. Transcriptional cross-talk, the second mode of steroid hormone receptor action. J. Mol. Med. 1998, 76, 480-489. [CrossRef] 
43. Liu, S.B.; Zhao, M.G. Neuroprotective effect of estrogen: Role of nonsynaptic NR2B-containing NMDA receptors. Brain Res. Bull. 2013, 93, 27-31. [CrossRef] [PubMed]

44. Meyer, M.R.; Haas, E.; Prossnitz, E.R.; Barton, M. Non-genomic regulation of vascular cell function and growth by estrogen. Mol. Cell. Endocrinol. 2009, 308, 9-16. [CrossRef] [PubMed]

45. Vail, G.; Roepke, T.A. Membrane-initiated estrogen signaling via Gq-coupled GPCR in the central nervous system. Steroids 2019, 142, 77-83. [CrossRef] [PubMed]

46. Toran-Allerand, C.D. Estrogen and the brain: Beyond ER- $\alpha$ and ER- $\beta$. Exp. Gerontol. 2004, 39, 1579-1586. [CrossRef] [PubMed]

47. Losel, R.; Wehling, M. Nongenomic actions of steroid hormones. Nat. Rev. Mol. Cell. Biol. 2003, 4, 46-56. [CrossRef]

48. Mellon, S.H.; Griffin, L.D. Neurosteroids: Biochemistry and clinical significance. Trends Endocrinol. Metab. 2002, 13, 35-43. [CrossRef]

49. Leranth, C.; Shanabrough, M.; Redmond, D.E., Jr. Gonadal hormones are responsible for maintaining the integrity of spine synapses in the CA1 hippocampal subfield of female nonhuman primates. J. Comp. Neurol. 2002, 447, 34-42. [CrossRef]

50. Hasegawa, Y.; Hojo, Y.; Kojima, H.; Ikeda, M.; Hotta, K.; Sato, R.; Ooishi, Y.; Yoshiya, M.; Chung, B.C.; Yamazaki, T.; et al. Estradiol rapidly modulates synaptic plasticity of hippocampal neurons: Involvement of kinase networks. Brain. Res. 2015, 1621, 147-161. [CrossRef]

51. Marx, C.E.; Stevens, R.D.; Shampine, L.J.; Uzunova, V.; Trost, W.T.; Butterfield, M.I.; Massing, M.W.; Hamer, R.M.; Morrow, A.L.; Lieberman, J.A. Neuroactive steroids are altered in schizophrenia and bipolar disorder: Relevance to pathophysiology and therapeutics. Neuropsychopharmacology 2006, 3, 1249-1263. [CrossRef] [PubMed]

52. Maggio, M.; De Vita, F.; Fisichella, A.; Colizzi, E.; Provenzano, S.; Lauretani, F.; Luci, M.; Ceresini, G.; Dall'Aglio, E.; Caffarra, P.; et al. DHEA and cognitive function in the elderly. J. Steroid Biochem. Mol. Biol. 2015, 145, 281-292. [CrossRef] [PubMed]

53. Yilmaz, C.; Karali, K.; Fodelianaki, G.; Gravanis, A.; Chavakis, T.; Charalampopoulos, I.; Alexaki, V.I. Neurosteroids as regulators of neuroinflammation. Front. Neuroendocrinol. 2019, 55, 100788. [CrossRef]

54. Hampson, E. Estrogen-related variations in human spatial and articulatory-motor skills. Psychoneuroendocrinology 1990, 15, 97-111. [CrossRef]

55. Kimura, D. Sex differences in the brain. Sci. Am. 1992, 267, 119-125. [CrossRef] [PubMed]

56. Sherwin, B.B.; Tulandi, T. “Add-back" estrogen reverses cognitive deficits induced by a gonadotropin-releasing hormone agonist in women with leiomyomata uteri. J. Clin. Endocrinol. Metab. 1996, 81, 2545-2549.

57. Smith, S. The effects of oestrogen and progesterone on GABA and glutamate responses at extrahypothalamic sites. In Neurosteroids and Brain Function; Costa, E., Paul, S.M., Eds.; Thieme Medical: New York, NY, USA, 1991; pp. 87-94.

58. Kimoto, T.; Tsurugizawa, T.; Ohta, Y.; Makino, J.; Tamura, H.; Hojo, Y.; Takata, N.; Kawato, S. Neurosteroid synthesis by cytochrome p450-containing systems localized in the rat brain hippocampal neurons: N-methyl-D-aspartate and calciumdependent synthesis. Endocrinology 2001, 142, 3578-3589. [CrossRef] [PubMed]

59. Kawato, S.; Hojo, Y.; Kimoto, T. Histological and metabolism analysis of P450 expression in the brain. Methods Enzymol. 2002, 357, 241-249.

60. Kawato, S.; Yamada, M.; Kimoto, T. Brain neurosteroids are 4th generation neuromessengers in the brain: Cell biophysical analysis of steroid signal transduction. Adv. Biophys. 2003, 37, 1-48. [CrossRef]

61. Hojo, Y.; Hattori, T.A.; Enami, T.; Furukawa, A.; Suzuki, K.; Ishii, H.T.; Mukai, H.; Morrison, J.H.; Janssen, W.G.; Kominami, S.; et al. Adult male rat hippocampus synthesizes estradiol from pregnenolone by cytochromes P45017alpha and P450 aromatase localized in neurons. Proc. Natl. Acad. Sci. USA 2004, 101, 865-870. [CrossRef]

62. Hojo, Y.; Murakami, G.; Mukai, H.; Higo, S.; Hatanaka, Y.; Ogiue-Ikeda, M.; Ishii, H.; Kimoto, T.; Kawato, S. Estrogen synthesis in the brain-role in synaptic plasticity and memory. Mol. Cell. Endocrinol. 2008, 290, 31-43. [CrossRef] [PubMed]

63. Murakami, G.; Tanabe, N.; Ishii, H.T.; Ogiue-Ikeda, M.; Tsurugizawa, T.; Mukai, H.; Hojo, Y.; Takata, N.; Furukawa, A.; Kimoto, T.; et al. Role of cytochrome p450 in synaptocrinology: Endogenous estrogen synthesis in the brain hippocampus. Drug Metab. Rev. 2006, 38, 353-369. [CrossRef] [PubMed]

64. Kretz, O.; Fester, L.; Wehrenberg, U.; Zhou, L.; Brauckmann, S.; Zhao, S.; Prange-Kiel, J.; Naumann, T.; Jarry, H.; Frotscher, M.; et al. Hippocampal synapses depend on hippocampal estrogen synthesis. J. Neurosci. 2004, 24, 5913-5921. [CrossRef] [PubMed]

65. Fester, L.; Ribeiro-Gouveia, V.; Prange-Kiel, J.; von Schassen, C.; Bottner, M.; Jarry, H.; Rune, G.M. Proliferation and apoptosis of hippocampal granule cells require local oestrogen synthesis. J. Neurochem. 2006, 97, 1136-1144. [CrossRef] [PubMed]

66. Prange-Kiel, J.; Fester, L.; Zhou, L.; Lauke, H.; Carretero, J.; Rune, G.M. Inhibition of hippocampal estrogen synthesis causes region-specific downregulation of synaptic protein expression in hippocampal neurons. Hippocampus 2006, 16, 464-471. [CrossRef] [PubMed]

67. Higo, S.; Hojo, Y.; Ishii, H.; Kominami, T.; Nakajima, K.; Poirier, D.; Kimoto, T.; Kawato, S. Comparison of sex-steroid synthesis between neonatal and adult rat hippocampus. Biochem. Biophys. Res. Commun. 2009, 385, 62-66. [CrossRef] [PubMed]

68. Ishii, H.; Tsurugizawa, T.; Ogiue-Ikeda, M.; Asashima, M.; Mukai, H.; Murakami, G.; Hojo, Y.; Kimoto, T.; Kawato, S. Local production of sex hormones and their modulation of hippocampal synaptic plasticity. Neuroscientist 2007, 13, 323-334. [CrossRef]

69. Hojo, Y.; Higo, S.; Ishii, H.; Ooishi, Y.; Mukai, H.; Murakami, G.; Kominami, T.; Kimoto, T.; Honma, S.; Poirier, D.; et al. Comparison between hippocampus-synthesized and circulation-derived sex steroids in the hippocampus. Endocrinology 2009, 150, 5106-5112. [CrossRef]

70. McEwen, B.S.; Alves, S.E. Estrogen actions in the central nervous system. Endocr. Rev. 1999, 20, 279-307. [CrossRef] 
71. Cui, J.; Shen, Y.; Li, R. Estrogen synthesis and signaling pathways during aging: From periphery to brain. Trends Mol. Med. 2013, 19, 197-209. [CrossRef]

72. Hewitt, S.C.; Korach, K.S. Estrogen Receptors: New Directions in the New Millennium. Endocr. Rev. 2018, 39, 664-675. [CrossRef] [PubMed]

73. Blakemore, J.; Naftolin, F. Aromatase: Contributions to Physiology and Disease in Women and Men. Physiology (Bethesda) 2016, 31, 258-269.

74. Hess, R.A.; Cooke, P.S. Estrogen in the male: A historical perspective. Biol. Reprod. 2018, 99, 27-44. [CrossRef]

75. Franks, S.; Hardy, K. Androgen Action in the Ovary. Front. Endocrinol. (Lausanne) 2018, 9, 452. [CrossRef] [PubMed]

76. Chianese, R.; Cobellis, G.; Chioccarelli, T.; Ciaramella, V.; Migliaccio, M.; Fasano, S.; Pierantoni, R.; Meccariello, R. Kisspeptins, estrogens and male fertility. Curr. Med. Chem. 2016, 23, 4070-4091. [CrossRef] [PubMed]

77. McCarthy, M.M. Estradiol and the Developing Brain. Physiol. Rev. 2008, 88, 91-124. [CrossRef] [PubMed]

78. Gegenhuber, B.; Tollkuhn, J. Sex Differences in the Epigenome: A Cause or Consequence of Sexual Differentiation of the Brain? Genes 2019, 10, 432. [CrossRef]

79. Santoro, A.; Chianese, R.; Troisi, J.; Richards, S.; Nori, S.L.; Fasano, S.; Guida, M.; Plunk, E.; Viggiano, A.; Pierantoni, R.; et al. Neuro-toxic and Reproductive Effects of BPA. Curr. Neuropharmacol. 2019, 17, 1109-1132. [CrossRef]

80. Sharpe, R.M. The roles of oestrogen in the male. Trends Endocrinol. Metab. 1998, 9, 371-377. [CrossRef]

81. Rochira, V.; Balestrieri, A.; Madeo, B.; Spaggiari, A.; Carani, C. Congenital estrogen deficiency in men: A new syndrome with different phenotypes; clinical and therapeutic implications in men. Mol. Cell. Endocrinol. 2002, 193, 19-28. [CrossRef]

82. Jones, M.E.; Boon, W.C.; Proietto, J.; Simpson, E.R. Of mice and men: The evolving phenotype of aromatase deficiency. Trends Endocrinol. Metab. 2006, 17, 55-64. [CrossRef] [PubMed]

83. Roselli, C.E.; Liu, M.; Hurn, P.D. Brain aromatization: Classic roles and new perspectives. Semin. Reprod. Med. 2009, 27, 207-217. [CrossRef] [PubMed]

84. Van den Buuse, M.; Simpson, E.R.; Jones, M.E. Prepulse inhibition of acoustic startle in aromatase knock-out mice: Effects of age and gender. Genes Brain Behav. 2003, 2, 93-102. [CrossRef] [PubMed]

85. Hill, R.A.; McInnes, K.J.; Gong, E.C.; Jones, M.E.; Simpson, E.R.; Boon, W.C. Estrogen deficient male mice develop compulsive behavior. Biol. Psychiatry 2007, 61, 359-366. [CrossRef] [PubMed]

86. Abraha 'm, I.M.; Herbison, A.E. Major sex differences in non-genomic estrogen actions on intracellular signaling in mouse brain in vivo. Neuroscience 2005, 131, 945-951. [CrossRef] [PubMed]

87. Murphy, D.D.; Segal, M. Morphological plasticity of dendritic spines in central neurons is mediated by activation of cAMP response element binding protein. Proc. Natl. Acad. Sci. USA 1997, 94, 1482-1487. [CrossRef]

88. Frankfurt, M.; Gould, E.; Wolley, C.; McEwen, B.S. Gonadal steroids modify dendritic spine density in ventromedial hypothalamic neurons: A Golgi study in the adult rat. Neuroendocrinology 1990, 51, 530-535. [CrossRef] [PubMed]

89. Carrer, H.F.; Aoki, A. Ultrastructural changes in the hypothalamic ventromedial nucleus of ovariectomized rats after estrogen treatment. Brain Res. 1982, 240, 221-233. [CrossRef]

90. Frankfurt, M.; McEwen, B.S. Estrogen increases axodendritic synapses in the VMN of rats after ovariectomy. NeuroReport 1991, 2, 380-382. [CrossRef]

91. Gould, E.; Woolley, C.; Frankfurt, M.; McEwen, B.S. Gonadal steroids regulate dendritic spine density in hippocampal pyramidal cells in adulthood. J. Neurosci. 1990, 10, 1286-1291. [CrossRef]

92. Lewis, C.; McEwen, B.S.; Frankfurt, M. Estrogen-induction of dendritic spines in ventromedial hypothalamus and hippocampus: Effects of neonatal aromatase blockade and adult castration. Dev. Brain Res. 1995, 87, 91-95. [CrossRef]

93. Amantea, D.; Spagnuolo, P.; Bari, M.; Fezza, F.; Mazzei, C.; Tassorelli, C.; Morrone, L.A.; Corasaniti, M.T.; Maccarone, M.; Bagetta, G. Modulation of the endocannabinoid system by focal brain ischemia in the rat is involved in neuroprotection afforded by 17 beta-estradiol. FEBS J. 2007, 274, 4464-4475. [CrossRef] [PubMed]

94. Hill, M.N.; Karacabely, E.S.; Gorzalka, B. Estrogen recruits the endocannabinoid system to modulate emotionality. Psychoneuroendocrinology 2007, 32, 350-357. [CrossRef] [PubMed]

95. Vallée, M.; Vitiello, S.; Bellocchio, L.; Hébert-Chatelain, E.; Reggio, P.H.; Ross, R.A.; Marsicano, G.; Piazza, P.V. Pregnenolone can protect the brain from cannabis intoxication. Science 2014, 343, 94-98. [CrossRef] [PubMed]

96. Rasmusson, A.M.; Marx, C.E.; Pineles, S.L.; Locci, A.; Scioli-Salter, E.R.; Nillni, Y.I.; Liang, J.J.; Pinna, G. Neuroactive steroids and PTSD treatment. Neurosci. Lett. 2017, 10, 156-163. [CrossRef] [PubMed]

97. Pierantoni, R.; Cobellis, G.; Meccariello, R.; Fasano, S. Evolutionary aspects of cellular communication in the vertebrate hypothalamo-hypophysio-gonadal axis. Int. Rev. Cytol. 2002, 218, 69-141. [PubMed]

98. Pinilla, L.; Aguilar, E.; Dieguez, C.; Millar, R.P.; Tena-Sempere, M. Kisspeptins and Reproduction: Physiological Roles and Regulatory Mechanisms. Physiol. Rev. 2012, 92, 1235-1316. [CrossRef]

99. Moenter, S.M.; Silveira, M.A.; Wang, L.; Adams, C.J. Central aspects of systemic oestradiol negative- and positive-feedback on the reproductive neuroendocrine system. Neuroendocrinology 2020, 32, 12724. [CrossRef]

100. Hewitt, S.C.; Winuthayanon, W.; Korach, K.S. What's new in estrogen receptor action in the female reproductive tract. J. Mol. Endocrinol. 2016, 56, 55-71. [CrossRef]

101. Meccariello, R.; Chianese, R.; Chioccarelli, T.; Ciaramella, V.; Fasano, S.; Pierantoni, R.; Cobellis, G. Intratesticular signals regulate germ cell progression and production of qualitatively mature spermatozoa in vertebrates. Front. Endocrinol. 2014, 5, 69. [CrossRef] 
102. Chianese, R.; Troisi, J.; Richards, S.; Scafuro, M.; Fasano, S.; Guida, M.; Pierantoni, R.; Meccariello, R. Bisphenol A in reproduction: Epigenetic effects. Curr. Med. Chem. 2018, 25, 748-770. [CrossRef] [PubMed]

103. D'Angelo, S.; Scafuro, M.; Meccariello, R. BPA and nutraceuticals, simultaneous effects on endocrine functions. Endocr. Metab. Immune Disord. Drug Targets 2019, 19, 594-604. [CrossRef] [PubMed]

104. Meccariello, R.; Santoro, A.; D'Angelo, S.; Morrone, R.; Fasano, S.; Viggiano, A.; Pierantoni, R. The epigenetics of the Endocannabinoid system. Int. J. Mol. Sci. 2020, 21, 1113. [CrossRef] [PubMed]

105. Wang, H.; Dey, S.K.; Maccarrone, M. Jekyll and Hyde: Two Faces of Cannabinoid Signaling in Male and Female Fertility. Endocr. Rev. 2006, 27, 427-448. [CrossRef] [PubMed]

106. Bovolin, P.; Cottone, E.; Pomatto, V.; Fasano, S.; Pierantoni, R.; Cobellis, G.; Meccariello, R. Endocannabinoids are involved in male vertebrate reproduction: Regulatory mechanisms at central and gonadal level. Front. Endocrinol. 2014, 5, 54. [CrossRef]

107. Schuel, H.; Burkman, L.J.; Lippes, J.; Crickard, K.; Forester, E.; Piomelli, D.; Giuffrida, A. N-Acylethanolamines in human reproductive fluids. Chem. Phys. Lipids 2002, 121, 211-227. [CrossRef]

108. Meccariello, R.; Battista, N.; Bradshaw, H.B.; Wang, H. Updates in reproduction coming from the endocannabinoid system. Int. J. Endocrinol. 2014, 2014, 412354. [CrossRef]

109. Brents, L.K. Marijuana, the Endocannabinoid System and the Female Reproductive System. Yale J. Biol. Med. 2016, 89, 175-191.

110. Battista, N.; Meccariello, R.; Cobellis, G.; Fasano, S.; Di Tommaso, M.; Pirazzi, V.; Konje, J.C.; Pierantoni, R.; Maccarrone, M. The role of endocannabinoids in gonadal function and fertility along the evolutionary axis. Mol. Cell. Endocrinol. 2012, 355, 1-14. [CrossRef]

111. Cobellis, G.; Meccariello, R.; Chianese, R.; Chioccarelli, T.; Fasano, S.; Pierantoni, R. Effects of neuroendocrine CB1 activity on adult Leydig cells. Front. Endocrinol. 2016, 7, 47. [CrossRef]

112. Du Plessis, S.S.; Agarwal, A.; Syriac, A. Marijuana, phytocannabinoids, the endocannabinoid system, and male fertility. J. Assist Reprod. Genet. 2015, 32, 1575-1588. [CrossRef] [PubMed]

113. Walker, O.S.; Holloway, A.C.; Raha, S. The role of the endocannabinoid system in female reproductive tissues. J. Ovarian Res. 2019, 12, 3-10. [CrossRef] [PubMed]

114. Takeda, S.; Yoshida, K.; Nishimura, H.; Harada, M.; Okajima, S.; Miyoshi, H.; Okamoto, Y.; Amamoto, T.; Watanabe, K.; Omiecinski, C.J.; et al. $\Delta(9)$-Tetrahydrocannabinol disrupts estrogen-signaling through up-regulation of estrogen receptor $\beta$ (ERß). Chem. Res. Toxicol. 2013, 26, 1073-1079. [CrossRef] [PubMed]

115. Fiori, J.L.; Sanghvi, M.; O'Connell, M.P.; Krzysik-Walker, S.M.; Moaddel, R.; Bernier, M. EGF receptor and its ligands via destabilization of estrogen-related receptor $\alpha$ protein. Br. J. Pharmacol. 2011, 164, 1026-1040. [CrossRef] [PubMed]

116. Wang, H.; Xie, H.; Guo, Y.; Zhang, H.; Takahashi, T.; Kingsley, P.J.; Marnett, L.J.; Das, S.K.; Cravatt, B.F.; Dey, S.K. Fatty acid amide hydrolase deficiency limits early pregnancy events. J. Clin. Investig. 2006, 116, 2122-2131. [CrossRef] [PubMed]

117. Buckley, N.E. The peripheral cannabinoid receptor knockout mice: An update. Br. J. Pharmacol. 2008, 153, 309-318. [CrossRef] [PubMed]

118. Sun, X.; Wang, H.; Okabe, M.; Mackie, K.; Kingsley, P.J.; Marnett, L.J.; Cravatt, B.F.; Dey, S.K. Genetic loss of FAAH compromises male fertility in mice. Biol. Reprod. 2009, 80, 235-242. [CrossRef]

119. Sun, X.; Dey, S.S. Endocannabinoid Signaling in Female Reproduction. ACS Chem. Neurosci. 2012, 3, 349-355. [CrossRef] [PubMed]

120. Acone, G.; Trabucco, E.; Colacurci, N.; Cobellis, L.; Mackie, K.; Meccariello, R.; Cacciola, G.; Chioccarelli, T.; Fasano, S.; Pierantoni, R.; et al. Low type I cannabinoid receptor levels characterize placental villous in labouring delivery. Placenta 2009, 30, $203-205$. [CrossRef]

121. Trabucco, E.; Acone, G.; Marenna, A.; Pierantoni, R.; Cacciola, G.; Chioccarelli, T.; Mackie, K.; Fasano, S.; Colacurci, N.; Meccariello, R.; et al. Endocannabinoid System in First Trimester Placenta: Low FAAH and High CB1 Expression Characterize Spontaneous Miscarriage. Placenta 2009, 30, 516-522. [CrossRef]

122. Li, Y.; Bian, F.; Sun, X.; Dey, S.K. Mice Missing Cnr1 and Cnr2 Show Implantation Defects. Endocrinology 2019, 160, 938-946. [CrossRef] [PubMed]

123. Cobellis, G.; Ricci, G.; Cacciola, G.; Orlando, P.; Petrosino, S.; Cascio, M.G.; Bisogno, T.; De Petrocellis, L.; Chioccarelli, T.; Altucci, L.; et al. A Gradient of 2-Arachidonoylglycerol Regulates Mouse Epididymal Sperm Cell Start-Up. Biol. Reprod. 2010, 82, 451-458. [CrossRef] [PubMed]

124. Chioccarelli, T.; Cacciola, G.; Altucci, L.; Lewis, S.E.; Simon, L.; Ricci, G.; Ledent, C.; Meccariello, R.; Fasano, S.; Pierantoni, R.; et al. Cannabinoid Receptor 1 Influences Chromatin Remodeling in Mouse Spermatids by Affecting Content of Transition Protein 2 mRNA and Histone Displacement. Endocrinology 2010, 151, 5017-5029. [CrossRef] [PubMed]

125. Chioccarelli, T.; Manfrevola, F.; Porreca, V.; Fasano, S.; Altucci, L.; Pierantoni, R.; Cobellis, G. The Cannabinoid Receptor CB1 Stabilizes Sperm Chromatin Condensation Status During Epididymal Transit by Promoting Disulphide Bond Formation. Int. J. Mol. Sci. 2020, 21, 3117. [CrossRef] [PubMed]

126. Cacciola, G.; Chioccarelli, T.; Altucci, L.; Viggiano, A.; Fasano, S.; Pierantoni, R.; Cobellis, G. Nuclear size as estrogen-responsive chromatin quality parameter of mouse spermatozoa. Gen. Comp. Endocrinol. 2013, 193, 2019. [CrossRef] [PubMed]

127. Cacciola, G.; Chioccarelli, T.; Altucci, L.; Ledent, C.; Mason, J.I.; Fasano, S.; Pierantoni, R.; Cobellis, G. Low 17beta-estradiol levels in CNR1 knock-out mice affect spermatid chromatin remodeling by interfering with chromatin reorganization. Biol. Reprod. 2013, 88, 152. [CrossRef] [PubMed] 
128. Maia, J.; Almada, M.; Silva, A.; Correia-da-Silva, G.; Teixeira, N.; Sá, S.I.; Fonseca, B.M. The endocannabinoid system expression in the female reproductive tract is modulated by estrogen. J. Steroid Biochem. Mol. Biol. 2017, 74, 40-47. [CrossRef]

129. Ernst, J.; Grabiec, U.; Greither, T.; Fischer, B.; Dehghani, F. The endocannabinoid system in the human granulosa cell line KGN. Mol. Cell. Endocrinol. 2016, 423, 67-76. [CrossRef]

130. Waleh, N.S.; Cravatt, B.F.; Apte-Deshpande, A.; Terao, A.; Kildu, T.S. Transcriptional regulation of the mouse fatty acid amide hydrolase gene. Gene 2002, 291, 203-210. [CrossRef]

131. Ciaramella, V.; Meccariello, R.; Chioccarelli, T.; Sirleto, M.; Fasano, S.; Pierantoni, R.; Chianese, R. Anandamide acts via kisspeptin in the regulation of testicular activity of the frog, Pelophylax esculentus. Mol. Cell. Endocrinol. 2016, 420, 75-84. [CrossRef]

132. Grimaldi, P.; Pucci, M.; Di Siena, S.; Di Giacomo, D.; Pirazzi, V.; Geremia, R.; Maccarrone, M. The FAAH gene is the first direct target of estrogen in the testis: Role of histone demethylase LSD1. Cell. Mol. Life Sci. 2012, 69, 4177-4190. [CrossRef] [PubMed]

133. Rossi, G.; Gasperi, V.; Paro, R.; Barsacchi, D.; Cecconi, S.; Maccarrone, M. Follicle-stimulating hormone activates fatty acid amide hydrolase by protein kinase A and aromatase-dependent pathways in mouse primary Sertoli cells. Endocrinology 2007, 148, 1431-1439. [CrossRef] [PubMed]

134. Farkas, I.; Kalló, I.; Deli, L.; Vida, B.; Hrabovszky, E.; Fekete, C.; Moenter, S.M.; Watanabe, M.; Liposits, Z. Retrograde endocannabinoid signaling reduces GABAergic synaptic transmission to gonadotropin-releasing hormone neurons. Endocrinology 2010, 151, 5818-5829. [CrossRef] [PubMed]

135. Meccariello, R.; Franzoni, M.F.; Chianese, R.; Cottone, E.; Scarpa, D.; Donna, D.; Cobellis, G.; Guastalla, A.; Pierantoni, R.; Fasano, S. Interplay between the endocannabinoid system and GnRH-I in the forebrain of the anuran amphibian Rana esculenta. Endocrinology 2008, 149, 2149-2158. [CrossRef]

136. Bálint, F.; Liposits, Z.; Farkas, I. Estrogen Receptor Beta and 2-arachidonoylglycerol Mediate the Suppressive Effects of Estradiol on Frequency of Postsynaptic Currents in Gonadotropin-Releasing Hormone Neurons of Metestrous Mice: An Acute Slice Electrophysiological Study. Front. Cell. Neurosci. 2016, 10, 77. [CrossRef]

137. Vazquez, M.J.; Velasco, I.; Tena-Sempere, M. Novel mechanisms for the metabolic control of puberty: Implications for pubertal alterations in early-onset obesity and malnutrition. J. Endocrinol. 2019, 242, 51-65. [CrossRef]

138. D'Angelo, S.; Motti, M.L.; Meccariello, R. $\omega-3$ and w-6 Polyunsaturated Fatty Acids, Obesity and Cancer. Nutrients 2020, $12,2751$. [CrossRef]

139. Forte, N.; Fernández-Rilo, A.C.; Palomba, L.; Di Marzo, V.; Cristino, L. Obesity Affects the Microbiota-Gut-Brain Axis and the Regulation Thereof by Endocannabinoids and Related Mediators. Int. J. Mol. Sci. 2020, 21, 1554. [CrossRef]

140. Pucci, M.; Zaplatic, E.; Micioni Di Bonaventura, M.V.; Micioni Di Bonaventura, E.; Paolo De Cristofaro, P.; Maccarrone, M.; Cifani, C.; D'Addario, C. On the Role of Central Type-1 Cannabinoid Receptor Gene Regulation in Food Intake and Eating Behaviors. Int. J. Mol. Sci. 2021, 22, 398. [CrossRef]

141. Washburn, N.; Borgquist, A.; Wang, K.; Jeffery, G.S.; Kelly, M.J.; Wagner, E.J. Receptor subtypes and signal transduction mechanisms contributing to the estrogenic attenuation of cannabinoid-induced changes in energy homeostasis. Neuroendocrinology 2013, 97, 160-175. [CrossRef]

142. Meccariello, R.; Fasano, S.; Pierantoni, R. Kisspeptins, new local modulators of male reproduction: A comparative overview. Gen. Comp. Endocrinol. 2020, 299, 113618. [CrossRef] [PubMed]

143. Motti, M.L.; Meccariello, R. Minireview: The epigenetic modulation of KISS1 in cancer and reproduction. Int. J. Environ. Res. Public Health 2019, 16, 2607. [CrossRef] [PubMed]

144. Karamikheirabad, M.; Behzadi, G.; Faghihi, M.; Raoofian, R.; Ejtemaei-Mehr, S.; Zuure, W.A.; Sadeghipour, H.R. A role for endocannabinoids in acute stress-induced suppression of the hypothalamic-pituitary-gonadal axis in male rats. Clin. Exp. Reprod. Med. 2013, 40, 155-162. [CrossRef] [PubMed]

145. Cobellis, G.; Cacciola, G.; Scarpa, D.; Meccariello, R.; Chianese, R.; Franzoni, M.F.; Mackie, K.; Pierantoni, R.; Fasano, S. Endocannabinoid system in frog and rodent testis: Type-1 cannabinoid receptor and fatty acid amide hydrolase activity in male germ cells. Biol. Reprod. 2006, 75, 82-89. [CrossRef] [PubMed]

146. Meccariello, R.; Chianese, R.; Cacciola, G.; Cobellis, G.; Pierantoni, R.; Fasano, S. Type-1 cannabinoid receptor expression in the frog, Rana esculenta, tissues: A possible involvement in the regulation of testicular activity. Mol. Reprod. Dev. 2006, 73, 551-558. [CrossRef]

147. Chianese, R.; Cobellis, G.; Pierantoni, R.; Fasano, S.; Meccariello, R. Non mammalian vertebrate models and the endocannabinoid system: Relationships with gonadotropin-releasing hormone. Mol. Cell. Endocrinol. 2008, 286, 46-51. [CrossRef] [PubMed]

148. Chianese, R.; Ciaramella, V.; Fasano, S.; Pierantoni, R.; Meccariello, R. Anandamidemodulates the expression of GnRH-II and GnRHRs in frog, Rana esculenta, diencephalon. Gen. Comp. Endocrinol. 2011, 173, 389-395. [CrossRef]

149. Chianese, R.; Ciaramella, V.; Scarpa, D.; Fasano, S.; Pierantoni, R.; Meccariello, R. Anandamide regulates the expression of GnRH-I, GnRH-II and GnRHRs in frog testis. Am. J. Physiol. Endrocrinol. Metab. 2012, 303, 475-487. [CrossRef]

150. Chianese, R.; Ciaramella, V.; Fasano, S.; Pierantoni, R.; Meccariello, R. Hypothalamus-pituitary axis: An obligatory target for endocannabinoids to inhibit steroidogenesis in frog testis. Gen. Comp. Endocrinol. 2014, 205, 88-93. [CrossRef]

151. Chianese, R.; Ciaramella, V.; Scarpa, D.; Fasano, S.; Pierantoni, R.; Meccariello, R. Endocannabinoids and endovanilloids: A possible balance in the regulation of the testicular GnRH signalling. Int. J. Endocrinol. 2013, 2013, 904748. [CrossRef]

152. Ciaramella, V.; Chianese, R.; Pariante, P.; Fasano, S.; Pierantoni, R.; Meccariello, R. Expression analysis of Gnrh1 and Gnrhr1 in spermatogenic cells of rat. Int. J. Endocrinol. 2015, 2015, 982726. [CrossRef] [PubMed] 
153. Chianese, R.; Ciaramella, V.; Fasano, S.; Pierantoni, R.; Meccariello, R. Kisspeptin Receptor, GPR54, as a Candidate for the Regulation of Testicular Activity in the Frog, Rana esculenta. Biol. Reprod. 2013, 88, 73. [CrossRef] [PubMed]

154. Chianese, R.; Ciaramella, V.; Fasano, S.; Pierantoni, R.; Meccariello, R. Kisspeptin drives germ cell progression in the anuran amphibian Pelophylax esculentus: A study carried out in ex vivo testes. Gen. Comp. Endocrinol. 2015, 211, 81-91. [CrossRef] [PubMed]

155. Chianese, R.; Ciaramella, V.; Fasano, S.; Pierantoni, R.; Meccariello, R. Kisspeptin regulates steroidogenesis and spermiation in the anuran amphibian Pelophylax esculentus testis. Reproduction 2017, 154, 403-414. [CrossRef] [PubMed]

156. Kabir, E.R.; Rahman, M.S.; Rahman, I. A review on endocrine disruptors and their possible impacts on human health. Environ. Toxicol. Pharmacol. 2015, 40, 241-258. [CrossRef] [PubMed]

157. Kiyama, R.; Wada-Kiyama, Y. Estrogenic endocrine disruptors: Molecular mechanisms of action. Environ. Int. 2015, 83, 11-40. [CrossRef] [PubMed]

158. Nowak, K.; Ratajczak-Wrona, W.; Górska, M.; Jabłońska, E. Parabens and their effects on the endocrine system. Mol. Cell. Endocrinol. 2018, 474, 238-251. [CrossRef]

159. Grimaldi, M.; Boulahtouf, A.; Delfosse, V.; Thouennon, E.; Bourguet, W.; Balaguer, P. Reporter cell lines for the characterization of the interactions between human nuclear receptors and endocrine disruptors. Front. Endocrinol. (Lausanne) 2015, 11, 62. [CrossRef]

160. Corrales, J.; Kristofco, L.A.; Steele, W.B.; Yates, B.S.; Breed, C.S.; Williams, E.S.; Brooks, B.W. Global Assessment of Bisphenol A in the Environment: Review and Analysis of Its Occurrence and Bioaccumulation. Dose-Response 2015, 13, 1559325815598308. [CrossRef]

161. Wang, Y.; Zhu, H.; Kannan, K. A Review of Biomonitoring of Phthalate Exposures. Toxics 2019, 7, 21. [CrossRef]

162. Li, K.; Gao, P.; Xiang, P.; Zhang, X.; Cui, X.; Ma, L.Q. Molecular mechanisms of PFOA-induced toxicity in animals and humans: Implications for health risks. Environ. Int. 2017, 99, 43-54. [CrossRef] [PubMed]

163. Morck, T.J.; Sorda, G.; Bechi, N.; Rasmussen, B.S.; Nielsen, J.B.; Ietta, F.; Rytting, E.; Mathiesen, L.; Paulesu, L.; Knudsen, L.E. Placental transport and in vitroeffects of Bisphenol A. Reprod. Toxicol. 2010, 30, 131-137. [CrossRef] [PubMed]

164. Corbel, T.; Gayrard, V.; Puel, S.; Lacroix, M.Z.; Berrebi, A.; Gil, S.; Viguie, C.; Toutain, P.L.; Picard-Hagen, N. Bidirectional placental transfer of Bisphenol A and its main metabolite, Bisphenol A Glucuronide, in the isolated perfused human placenta. Reprod. Toxicol. 2014, 47, 51-58. [CrossRef] [PubMed]

165. Di Pietro, P.; D’Auria, R.; Viggiano, A.; Ciaglia, E.; Meccariello, R.; Russo, R.D.; Puca, A.A.; Vecchione, C.; Nori, S.L.; Santoro, A. Bisphenol A induces DNA damage in cells exerting immune surveillance functions at peripheral and central level. Chemosphere 2020, 254, 126819. [CrossRef] [PubMed]

166. Chianese, R.; Viggiano, A.; Urbanek, K.; Cappetta, D.; Troisi, J.; Scafuro, M.; Guida, M.; Esposito, G.; Ciuffreda, L.P.; Rossi, F.; et al. Chronic exposure to low dose of bisphenol A impacts on the first round of spermatogenesis via SIRT1 modulation. Sci. Rep. 2018, 8, 2961. [CrossRef] [PubMed]

167. Boberg, J.; Axelstad, M.; Svingen, T.; Mandrup, K.; Christiansen, S.; Vinggaard, A.M.; Hass, U. Multiple endocrine disrupting effects in rats perinatally exposed tobutylparaben. Toxicol. Sci. 2016, 152, 244-256. [CrossRef]

168. Smarr, M.M.; Sundaram, R.; Honda, M.; Kannan, K.; Louis, G.M.B. Urinary concentrations of parabens and other antimicrobial chemicals and their association with couples' fecundity. Environ. Health Perspect. 2017, 125, 730-736. [CrossRef]

169. Smith, K.W.; Souter, I.; Dimitriadis, I.; Ehrlich, S.; Williams, P.L.; Calafat, A.M.; Hauser, R. Urinary paraben concentrations and ovarian aging among women from a fertility center. Environ. Health Perspect. 2013, 121, 1299-1305. [CrossRef]

170. Ali, E.H.; Elgoly, A.H. Combined prenatal and postnatal butyl paraben exposureproduces autism-like symptoms in offspring: Comparison with valproic acid autistic model. Pharmacol. Biochem. Behav. 2013, 111, 102-110. [CrossRef]

171. Lara-Valderrábano, L.; Galván, E.J.; Rocha, L. Propylparaben suppresses epileptiform activity in hippocampal CA1 pyramidal cells in vitro. Epilepsy Res. 2017, 136, 126-129. [CrossRef]

172. Kodani, S.D.; Overby, H.B.; Morisseau, C.; Chen, J.; Zhao, L.; Hammock, B.D. Parabens inhibit fatty acid amide hydrolase: A potential role in paraben-enhanced 3T3-L1 adipocyte differentiation. Toxicol. Lett. 2016, 262, 92-99. [CrossRef] [PubMed]

173. Forner-Piquer, I.; Santangeli, S.; Maradonna, F.; Verde, R.; Piscitelli, F.; Di Marzo, V.; Habibi, H.R.; Carnevali, O. Role of Bisphenol A on the Endocannabinoid System at central and peripheral levels: Effects on adult female zebrafish. Chemosphere 2018, 205, 118-125. [CrossRef] [PubMed]

174. Forner-Piquer, I.; Mylonas, C.C.; Calduch-Giner, J.; Maradonna, F.; Gioacchini, G.; Allarà, M.; Piscitelli, F.; Di Marzo, V.; PérezSánchez, J.; Carnevali, O. Endocrine disruptors in the diet of male Sparus aurata: Modulation of the endocannabinoid system at the hepatic and central level by Di-isononyl phthalate and Bisphenol A. Environ. Int. 2018, 119, 54-65. [CrossRef] [PubMed]

175. Cocci, P.; Mozzicafreddo, M.; Angeletti, M.; Mosconi, G.; Palermo, F.A. Differential tissue regulation of peroxisome proliferatoractivated receptor $\alpha(\mathrm{PPAR} \alpha)$ and cannabinoid receptor 1 (CB1) gene transcription pathways by diethylene glycol dibenzoate (DEGB): Preliminary observations in a seabream (Sparus aurata) in vivo model. Environ. Toxicol. Pharmacol. 2017, 55, 87-93. [CrossRef] [PubMed]

176. Pomatto, V.; Palermo, F.; Mosconi, G.; Cottone, E.; Cocci, P.; Nabissi, M.; Borgio, L.; Polzonetti-Magni, A.M.; Franzoni, M.F. Xenoestrogens elicit a modulation of endocannabinoid system and estrogen receptors in $4 \mathrm{NP}$ treated goldfish, Carassius auratus. Gen. Comp. Endocrinol. 2011, 174, 30-35. [CrossRef]

177. Forner-Piquer, I.; Beato, S.; Piscitelli, F.; Santangeli, S.; Di Marzo, V.; Habibi, H.R.; Maradonna, F.; Carnevali, O. Effects of BPA on zebrafish gonads: Focus on the endocannabinoid system. Environ. Pollut. 2020, 264, 114710. [CrossRef] [PubMed] 
178. Forner-Piquer, I.; Fakriadis, I.; Mylonas, C.C.; Piscitelli, F.; Di Marzo, V.; Maradonna, F.; Calduch-Giner, J.; Pérez-Sánchez, J.; Carnevali, O. Effects of Dietary Bisphenol A on the Reproductive Function of Gilthead Sea Bream (Sparus aurata) Testes. Int. J. Mol. Sci. 2019, 20, 5003. [CrossRef]

179. Forner-Piquer, I.; Mylonas, C.C.; Fakriadis, I.; Papadaki, M.; Piscitelli, F.; Di Marzo, V.; Calduch-Giner, J.; Pérez-Sánchez, J.; Carnevali, O. Effects of diisononyl phthalate (DiNP) on the endocannabinoid and reproductive systems of male gilthead sea bream (Sparus aurata) during the spawning season. Arch. Toxicol. 2019, 93, 727-741. [CrossRef]

180. Rossi, G.; Dufrusine, B.; Lizzi, A.R.; Luzi, C.; Piccoli, A.; Fezza, F.; Iorio, R.; D’Andrea, G.; Dainese, E.; Cecconi, S.; et al. Bisphenol A Deranges the Endocannabinoid System of Primary Sertoli Cells with an Impact on Inhibin B Production. Int. J. Mol. Sci. 2020, 21, 8986. [CrossRef]

181. Zbucka-Kretowska, M.; Zbucki, R.; Parfieniuk, E.; Maslyk, M.; Lazarek, U.; Miltyk, W.; Czerniecki, J.; Wolczynski, S.; Kretowski, A.; Ciborowski, M. Evaluation of Bisphenol A influence on endocannabinoid system in pregnant women. Chemosphere 2018, 203, 387-392. [CrossRef]

182. Zamkowska, D.; Karwacka, A.; Jurewicz, J.; Radwan, M. Environmental exposure to non persistent endocrine disrupting chemicals and semen quality: An overview of the current epidemiological evidence. Int. J. Occup. Med. Environ. Health 2018, 31, 377-414. [CrossRef] [PubMed]

183. Den Hond, E.; Tournaye, H.; De Sutter, P.; Ombelet, W.; Baeyens, W.; Covaci, A.; Cox, B.; Nawrot, T.S.; Van Larebeke, N.; D'Hooghe, T. Human exposure to endocrine disrupting chemicals and fertility: A case-control study in male subfertility patients. Environ. Int. 2015, 84, 154-160. [CrossRef] [PubMed]

184. Desai, M.; Jellyman, J.K.; Ross, M.G. Epigenomics, gestational programming and risk of metabolic syndrome. Int. J. Obes. 2015, 39, 633-641. [CrossRef] [PubMed]

185. Gillette, R.; Son, M.J.; Ton, L.; Gore, A.C.; Crews, D. Passing experiences on to future generations: Endocrine disruptors and transgenerational inheritance of epimutations in brain and sperm. Epigenetics 2018, 13, 1106-1126. [CrossRef]

186. Maamar, M.B.; King, S.E.; Nilsson, E.; Beck, D.; Skinner, M.K. Epigenetic transgenerational inheritance of parent-of-origin allelic transmission of outcross pathology and sperm epimutations. Dev. Biol. 2020, 458, 106-119. [CrossRef]

187. Lee, S.Y.; Oh, S.M.; Chung, K.H. Estrogenic effects of marijuana smoke condensate and cannabinoid compounds. Toxicol. Appl. Pharmacol. 2006, 214, 270-278. [CrossRef]

188. Zufferey, F.; Donzé, N.; Rahban, R.; Senn, A.; Stettler, E.; Rudaz, S.; Nef, S.; Rossier, M.F. Semen endocannabinoids are correlated to sperm quality in a cohort of 200 young Swiss men. Andrology 2020, 8, 1126-1135. [CrossRef]

189. Ambrosini, A.; Zolese, G.; Ambrosi, S.; Ragni, L.; Tiano, L.; Littarru, G.; Bertoli, E.; Mantero, F.; Boscaro, M.; Balercia, G. Oleoylethanolamide protects human sperm cells from oxidation stress: Studies on cases of idiopathic infertility. Biol. Reprod. 2006, 74, 659-665. [CrossRef]

190. Bar, J.; Lahav, J.; Hod, M.; Ben-Rafael, Z.; Weinberger, I.; Brosens, J. Regulation of platelet aggregation and adenosinetriphosphate release in vitro by 17 beta-estradiol and medroxyprogesterone acetate in postmenopausal women. Thromb. Haemost. 2000, 84, 695-700.

191. Mendelsohn, M.E.; Karas, R.H. The protective effects of estrogen on the cardiovascular system. N. Engl. J. Med. 1999, 340, 1801-1811. [CrossRef]

192. Sachais, B.S. Platelet-endothelial interactions in atherosclerosis. Curr. Atheroscler. Rep. 2001, 3, 412-416. [CrossRef] [PubMed]

193. Stefano, G.B.; Prevot, V.; Beauvillain, J.C.; Cadet, P.; Fimiani, C.; Welters, I.; Fricchione, G.L.; Breton, C.; Lassalle, P.; Salzet, M.; et al. Cell-surface estrogen receptors mediate calcium-dependent nitric oxide release in human endothelia. Circulation 2000, 101, 1594-1597. [CrossRef] [PubMed]

194. Maccarrone, M.; Bari, M.; Battista, N.; Finazzi-Agrò, A. Estrogen stimulates arachidonoylethanolamide release from human endothelial cells and platelet activation. Blood 2002, 100, 4040-4048. [CrossRef] [PubMed]

195. Kunos, G.; Jarai, Z.; Batkai, S.; Goparaju, S.K.; Ishac, E.J.; Liu, J.; Wang, L.; Wagner, J.A. Endocannabinoids as cardiovascular modulators. Chem. Phys. Lipids 2000, 108, 159-168. [CrossRef]

196. Maccarrone, M.; Finazzi-Agrò, A. Endocannabinoids and their actions. Vitam. Horm. 2002, 65, 225-255. [PubMed]

197. Maccarrone, M.; Bari, M.; Di Rienzo, M.; Finazzi-Agrò, A.; Rossi, A. Progesterone activates fatty acid amide hydrolase (FAAH) promoter in human T lymphocytes through the transcription factor Ikaros. Evidence for a synergistic effect of leptin. J. Biol. Chem. 2003, 278, 32726-32732. [CrossRef]

198. Ramer, R.; Schwarz, R.; Hinz, B. Modulation of the Endocannabinoid System as a Potential Anticancer Strategy. Front. Pharmacol. 2019, 10, 430. [CrossRef]

199. Xu, X.; Liu, Y.; Huang, S.; Liu, G.; Xie, C.; Zhou, J.; Fan, W.; Li, Q.; Wang, Q.; Zhong, D.; et al. Overexpression of cannabinoid receptors CB1 and CB2 correlates with improved prognosis of patients with hepatocellular carcinoma. Cancer Genet. Cytogenet. 2006, 171, 31-38. [CrossRef]

200. Melck, D.; De Petrocellis, L.; Orlando, P.; Bisogno, T.; Laezza, C.; Bifulco, M.; Di Marzo, V. Suppression of nerve growth factor Trk receptors and prolactin receptors by endocannabinoids leads to inhibition of human breast and prostate cancer cell proliferation. Endocrinology 2000, 141, 118-126. [CrossRef]

201. Mimeault, M.; Pommery, N.; Wattez, N.; Bailly, C.; Henichart, J.P. Antiproliferative and apoptotic effects of anandamide in human prostatic cancer cell lines: Implication of epidermal growth factor receptor downregulation and ceramide production. Prostate 2003, 56, 1-12. [CrossRef] 
202. De Petrocellis, L.; Ligresti, A.; Schiano Moriello, A.; Iappelli, M.; Verde, R.; Stott, C.G.; Cristino, L.; Orlando, P.; Di Marzo, V. Non-THC cannabinoids inhibit prostate carcinoma growth in vitro and in vivo: Pro-apoptotic effects and underlying mechanisms. Br. J. Pharmacol. 2013, 168, 79-102. [CrossRef] [PubMed]

203. Chung, S.C.; Hammarsten, P.; Josefsson, A.; Stattin, P.; Granfors, T.; Egevad, L.; Mancini, G.; Lutz, B.; Bergh, A.; Fowler, C.J. A high cannabinoid CB 1 receptor immunoreactivity is associated with disease severity and outcome in prostate cancer. Eur. J. Cancer 2009, 45, 174-182. [CrossRef] [PubMed]

204. Czifra, G.; Varga, A.; Nyeste, K.; Marincsák, R.; Tóth, B.I.; Kovács, I.; Kovács, L.; Bíró, T. Increased expressions of cannabinoid receptor-1 and transient receptor potential vanilloid-1 in human prostate carcinoma. J. Cancer Res. Clin. Oncol. 2009, 135, 507-514. [CrossRef] [PubMed]

205. Caffarel, M.M.; Andradas, C.; Mira, E.; Pérez-Gómez, E.; Cerutti, C.; Moreno-Bueno, G.; Flores, J.M.; García-Real, I.; Palacios, J.; Mañes, S.; et al. Cannabinoids reduce ErbB2-driven breast cancer progression through Akt inhibition. Mol. Cancer 2010, 9, 196. [CrossRef]

206. De Petrocellis, L.; Melck, D.; Palmisano, A.; Bisogno, T.; Laezza, C.; Bifulco, M.; Di Marzo, V. The endogenous cannabinoid anandamide inhibits human breast cancer cell proliferation. Proc. Natl. Acad. Sci. USA 1998, 95, 8375-8380. [CrossRef]

207. Laezza, C.; D'Alessandro, A.; Paladino, S.; Malfitano, A.M.; Proto, C.M.; Gazzerro, P.; Pisanti, S.; Santoro, A.; Ciaglia, E.; Bifulco, M. Anandamide inhibits the Wnt/ $\beta$-catenin signalling pathway in human breast cancer MDA MB 231 cells. Eur. J. Cancer 2012, 48, 3112-3122. [CrossRef]

208. Fonseca, B.M.; Correia-da-Silva, G.; Teixeira, N.A. Cannabinoid-induced cell death in endometrial cancer cells: Involvement of TRPV1 receptors in apoptosis. J. Physiol. Biochem. 2018, 74, 261-272. [CrossRef]

209. Hasenoehrl, C.; Feuersinger, D.; Sturm, E.M.; Bärnthaler, T.; Heitzer, E.; Graf, R.; Grill, M.; Pichler, M.; Beck, S.; Butcher, L.; et al. G protein-coupled receptor GPR55 promotes colorectal cancer and has opposing effects to cannabinoid receptor 1. Int. J. Cancer 2018, 142, 121-132. [CrossRef]

210. Santoro, A.; Pisanti, S.; Grimaldi, C.; Izzo, A.A.; Borrelli, F.; Proto, M.C.; Malfitano, A.M.; Gazzerro, P.; Laezza, C.; Bifulco, M. Rimonabant inhibits human colon cancer cell growth and reduces the formation of precancerous lesions in the mouse colon. Int. J. Cancer 2009, 125, 996-1003. [CrossRef]

211. Ligresti, A.; Bisogno, T.; Matias, I.; De Petrocellis, L.; Cascio, M.G.; Cosenza, V.; D’argenio, G.; Scaglione, G.; Bifulco, M.; Sorrentini, I.; et al. Possible endocannabinoid control of colorectal cancer growth. Gastroenterology 2003, 125, 677-687. [CrossRef]

212. Jacenik, D.; Beswick, E.J.; Krajewska, W.M.; Prossnitz, E.R. G protein-coupled estrogen receptor in colon function, immune regulation and carcinogenesis. World J. Gastroenterol. 2019, 25, 4092-4104. [CrossRef] [PubMed]

213. Williams, C.; DiLeo, A.; Niv, Y.; Gustafsson, J.A. Estrogen receptor beta as target for colorectal cancer prevention. Cancer Lett. 2016, 372, 48-56. [CrossRef] [PubMed]

214. Pisanti, S.; Malfitano, A.M.; Grimaldi, C.; Santoro, A.; Gazzerro, P.; Laezza, C.; Bifulco, M. Use of cannabinoid receptor agonists in cancer therapy as palliative and curative agents. Best Pract. Res. Clin. Endocrinol. Metab. 2009, 23, 117-131. [CrossRef] [PubMed]

215. Ligresti, A.; De Petrocellis, L.; Di Marzo, V. From Phytocannabinoids to Cannabinoid Receptors and Endocannabinoids: Pleiotropic Physiological and Pathological Roles through Complex Pharmacology. Physiol. Rev. 2016, 96, 1593-1659. [CrossRef] [PubMed]

216. Laezza, C.; Pagano, C.; Navarra, G.; Pastorino, O.; Proto, M.C.; Fiore, D.; Piscopo, C.; Gazzerro, P.; Bifulco, M. The Endocannabinoid System: A Target for Cancer Treatment. Int. J. Mol. Sci. 2020, 21, 747. [CrossRef]

217. Sarnataro, D.; Pisanti, S.; Santoro, A.; Gazzerro, P.; Malfitano, A.M.; Laezza, C.; Bifulco, M. The cannabinoid CB1 receptor antagonist rimonabant (SR141716) inhibits human breast cancer cell proliferation through a lipid raft-mediated mechanism. Mol. Pharmacol. 2006, 70, 1298-1306. [CrossRef]

218. Notarnicola, M.; Messa, C.; Orlando, A.; Bifulco, M.; Laezza, C.; Gazzerro, P.; Caruso, M.G. Estrogenicinduction of cannabinoid CB1 receptor in human colon cancercell lines. Scand. J. Gastroenterol. 2008, 43, 66-72. [CrossRef]

219. Guida, M.; Ligresti, A.; De Filippis, D.; D’Amico, A.; Petrosino, S.; Cipriano, M.; Bifulco, G.; Simonetti, S.; Orlando, P.; Insabato, L.; et al. The levels of the endocannabinoid receptor CB2 and its ligand 2-arachidonoylglycerol are elevated in endometrial carcinoma. Endocrinology 2010, 151, 921-928. [CrossRef]

220. Tavares, C.B.; Gomes-Braga, F.; Costa-Silva, D.R.; Escórcio-Dourado, C.S.; Borges, U.S.; Conde-Junior, A.M.; Barros-Oliveira, M.C.; Sousa, E.B.; Barros, L.R.; Martins, L.M.; et al. Expression of estrogen and progesterone receptors in astrocytomas: A literature review. Clinics 2016, 71, 481-486. [CrossRef]

221. Zhang, L.; Zhu, Y.; Cheng, H.; Zhang, J.; Zhu, Y.; Chen, H.; Chen, L.; Qi, H.; Ren, G.; Tang, J.; et al. The Increased Expression of Estrogen-Related Receptor $\alpha$ Correlates with Wnt5a and Poor Prognosis in Patients with Glioma. Mol. Cancer Ther. 2019, 18, 173-184. [CrossRef]

222. Wu, X.; Han, L.; Zhang, X.; Li, L.; Jiang, C.; Qiu, Y.; Huang, R.; Xie, B.; Lin, Z.; Ren, J.; et al. Alteration of endocannabinoid system in human gliomas. J. Neurochem. 2012, 120, 842-849. [CrossRef] [PubMed] 